\title{
Trade Liberalization and Firm Dynamics
}

\section{Citation}

Melitz, Marc, and Ariel Burstein. 2013. "Trade Liberalization and Firm Dynamics." In Advances in Economics and Econometrics: Tenth World Congress (Econometric Society Monographs), vol. 2, ed. Daron Acemoglu, Manuel Arellano, and Eddie Dekel, 283-328. Cambridge, UK: Cambridge University Press.

\section{Published Version}

doi:10.1017/CB09781139060028.008

\section{Permanent link}

http://nrs.harvard.edu/urn-3:HUL.InstRepos:34557509

\section{Terms of Use}

This article was downloaded from Harvard University's DASH repository, and is made available under the terms and conditions applicable to Open Access Policy Articles, as set forth at http:// nrs.harvard.edu/urn-3:HUL.InstRepos:dash.current.terms-of-use\#OAP

\section{Share Your Story}

The Harvard community has made this article openly available.

Please share how this access benefits you. Submit a story.

\section{Accessibility}




\title{
Trade Liberalization and Firm Dynamics*
}

\author{
Ariel Burstein \\ Marc J. Melitz \\ UCLA and NBER \\ Harvard University, NBER and CEPR
}

October 2011

\begin{abstract}
In this paper, we analyze the transition dynamics associated with an economy's response to trade liberalization. We start by reviewing the recent literature that incorporates firm dynamics into models of international trade. We then build upon that literature to characterize the role of firm dynamics, export-market selection, firm-level innovation, sunk export costs, and firms' expectations regarding the time path of liberalization in generating those transition dynamics following trade liberalization. These modeling ingredients generate substantial aggregate transition dynamics as they shift and shape the endogenous distribution of firms over time. Our results show how the responses of trade volumes, innovation, and aggregate output can vary greatly over time depending on those modeling ingredients. This has important consequences for many issues in international economics that rely on predictions for the effects of globalization over time on those key aggregate outcomes.
\end{abstract}

${ }^{*}$ We thank Javier Cravino for superb research assistance, and Daron Acemoglu and Steve Redding for many helpful comments and suggestions. 


\section{Introduction}

Firms operating in the same country and industry respond to globalization in very different ways. Empirical work using micro-level data on firms or plants initially highlighted this contrast for export decisions and how this decision correlates with observable firm performance measures such as size and productivity: only a subset of relatively bigger and more productive firms export. ${ }^{1}$ Subsequent work has documented a wide ranging set of other responses to globalization that consistently vary across firms in the same country and industry, and are also strongly correlated with firm-level performance measures: the number and location of export destinations, entry and exit from the domestic market, the range of products produced, the international organization of production (including but not limited to multinational status and outsourcing/offshoring decisions), and innovation activities such as R\&D.

This empirical work has prompted the development of models with heterogeneous firms in open economies that capture how changes in the extent of globalization (indexing frictions to trade and foreign investment, and the size of the global economy) influence those varied firm-level responses. These models highlight the composition effects that are induced by the different firm-level responses to globalization. In order to focus on those composition effects, the majority of models examine cases where the firms' responses to globalization (export decisions, organization of production, innovation) do not change over time. This assumes a stable aggregate environment with no firm dynamics

In this chapter, we focus on a relatively new direction in this literature examining how firm responses evolve over time to changes in the extent of globalization (with an emphasis on trade liberalization). Recent empirical work has documented the dynamic interactions among those firm responses, in particular between the export decision and innovation: trade liberalization increases the return to both firm activities, while each activity additionally affects the returns to the other. Clearly, such interactions will induce the mapping between firm characteristics and their export and innovation decisions to change over time. This provides one important rationale for the study of models that incorporate those dynamic interactions. Furthermore, the aggregation of those changing firm decisions along with the evolution of entry and exit generate substantial differences in the economy's overall response to globalization over time. This implies that an analysis of steady state

\footnotetext{
${ }^{1}$ Throughout this chapter, we refer to firms as the micro-level unit of production. Some of the empirical evidence we reference is based on more disaggregated plant-level data (which differentiates between a firm's different production locations).
} 
outcomes may give a misleading summary of the overall effects of liberalization. This is the second rationale for studying models that feature dynamic interactions in firm responses to liberalization: they are able to contrast the response of key economic aggregates to trade liberalization at different time horizons.

In the next section, we review theoretical models that capture some of these dynamics, and summarize the associated empirical evidence. Our focus in the current paper is to explain and motivate in a unified manner how key modeling ingredients of firm dynamics interact to generate endogenous aggregate transition dynamics. We develop a range of variants of this type of model to isolate different interactions and mechanisms. We analyze some of the simpler variants analytically, and computationally derive the transition dynamics for the others. We show how the response of innovative activities magnify the productivity differences between exporters and non-exporters. We examine how the responses of average productivity and trade flows can be significantly different to those in static trade models, and how these response can differ substantially at short and long term horizons, depending on the responses of entry, innovation, and the timing of trade liberalization.

We restrict our analysis to just one type of international market participation decision - export to a single destination - and one type of technology choice - innovation intensity - and focus on the key interactions between these two firm decisions in response to trade liberalization. We incorporate fixed export costs (potentially sunk), but assume that trade liberalization takes the form of reductions in the per-unit export costs. We separately consider two cases for innovation: One where innovation is exogenous to the firms, so that firm productivity evolves stochastically, but independently from any firm decisions; The other where innovation is endogenous and differs across firms and responds to changes in the aggregate trading environment. In all cases, incumbent firms also make endogenous exit decisions. When trade is liberalized, the aggregate transition dynamics reflect a combination of all those decisions by incumbent firms as well as the aggregate response of entry. We highlight how the interaction of both firm dynamics and endogenous export market selection jointly induce long lasting aggregate transition dynamics in response to a onetime unanticipated drop in that variable trade cost. We discuss how comparisons of consumption across steady-states can significantly over- or under-state welfare measures that take into account the transition dynamics. We also show how expectations regarding future trade costs give rise to their own transition dynamics: either because the drop in the trade cost is anticipated ex-ante, or because it is not expected to last ex-post (the trade liberalization is temporary).

In order to highlight the importance of the interaction between firm dynamics and export market 
selection, we develop analytical models that feature either one or the other, and show how, those models do not generate any endogenous transition dynamics in response to trade liberalization. These analytical cases show that the entrants' expectation regarding future potential export profits (relative to incumbent firms) is a key factor generating aggregate transition dynamics. Endogenous innovation by firms further amplifies productivity differences between exporters and non-exporters, and generates longer lasting transition dynamics. We show that trade liberalization even induces some non-exporters to increase their innovation activities (in spite of facing stronger competition in their domestic market), because they anticipate exporting in the future and respond to the associated higher returns post-liberalization. All of these dynamic effects imply large differences over time in the response of aggregate trade volumes to trade liberalization: long run trade elasticities (with respect to the fall in trade costs) are substantially higher than the corresponding short run elasticities.

We show that firms' expectations regarding trade liberalization are particularly relevant when innovation is endogenous. If trade liberalization is only expected to be temporary, then the amplification effect of endogenous innovation is weakened - and is no longer significantly different than for the exogenous innovation case. On the other hand, when trade liberalization is anticipated ex-ante, endogenous innovation induces a significant rise in innovation ahead of the drop in the trade cost. Differences in the response of innovation between exporters and non-exporters also amplify (endogenously) productivity differences between those two groups of firms. Lastly, we incorporate sunk trade costs to examine how trade liberalization affects the option value of becoming an exporter. This leads to additional anticipation effects ahead of the change in trade costs.

The remainder of the chapter is organized as follows. Section 2 presents a brief overview of the recent literature on trade liberalization and firm dynamics. Section 3 present our model and characterizes the equilibrium with two symmetric countries. Section 4 describes our model parameterization. Section 5 presents the theoretical and quantitative results for the different trade liberalization scenarios. The scenarios are designed to isolate the separate roles of export market participation, firm dynamics, endogenous innovation, sunk export costs, and anticipation effects regarding trade liberalization. Section 6 concludes. An Appendix presents proofs of our analytic results. 


\section{Literature Overview}

Workhorse general equilibrium models of heterogeneous firm dynamics in closed economies (such as Hopenhayn 1992, Atkeson and Kehoe 2005, and Luttmer 2007) recently have been extended to open economy settings. ${ }^{2}$ For example, Arkolakis (2008) and Irarrazabal and Opromolla (2008) consider dynamics extensions of Melitz (2003), in which firms experience exogenous random shocks to their productivity, to account for salient features of the data on firm dynamics by domestic and exporting firms. While these papers focus on stable aggregate environments, Alessandria and Choi (2007) and Ruhl (2008) examine the transition dynamics to trade liberalizations, focusing on the role of entry into domestic and export markets. ${ }^{3}$ Alessandria and Choi (2007) show, as we do below, that welfare calculations based on steady-state consumption comparisons can give significantly different answers than welfare calculations taking into account transition dynamics across steady-states. They also consider physical capital, which we abstract from, as another source of endogenous dynamics as in the neoclassical growth model. Other papers examine more specifically how firms make joint decisions regarding both export status and technology choice. For example, Bustos (2007), and Yeaple (2005) consider static models in which there is a binary technology choice, and highlight how firms jointly decide to both enter export markets and adopt the new technology (or do neither). ${ }^{4}$ Costantini and Melitz (2008) extend this type of joint decision to a dynamic framework where firms face both idiosyncratic uncertainty and sunk costs for both exporting and technology adoption. The sunk costs and uncertainty combine to generate option values for export and exit decisions. We explore the effects of those option values in the current chapter. Our model of innovation follows closely the model developed by Atkeson and Burstein (2010), which builds on Griliches' (1979) model of knowledge capital. As in Ericson and Pakes (1995) and more recently in Doraszelski and Jaumandreu (2008), the fruits of innovative activity are stochastic, so the model can account for simultaneous growth and decline, and entry and exit of firms in steady state. While Atkeson and Burstein (2010) focus on the offsetting responses of exit, export, innovation, and entry decisions to permanent trade liberalizations and the offsetting effects of changes in these decisions on aggregate productivity and welfare, we focus on the effects of changes in these decisions on transition dynamics of average productivity, trade flows, and output,

\footnotetext{
${ }^{2}$ See Luttmer (2010) for a comprehensive survey of aggregate models of firm dynamics.

${ }^{3}$ Buera and Shin (2010) examine the transition dynamics of aggregate productivity in response to reforms such as capital account liberalizations and removal of various micro distortions in economies with underdeveloped financial markets.

${ }^{4}$ See also the related work of Ederington and McCalman (2008), Navas-Ruiz and Sala (2007), Long, Raff, and Stähler (2008), and Rubini (2010).
} 
allowing for sunk export costs, considering both temporary and anticipated liberalizations.

While in this chapter we model firm dynamics arising from changes over time in productivity or product quality that affect firm's production for all markets simultaneously, a number of recent papers have focused on demand dynamics as firms accumulate customers in foreign markets. ${ }^{5}$ Ruhl and Willis (2008) introduce demand shifters that grow over time to explain the slow growth of exporters as they enter new markets. Eaton et al (2008) model firms' investments directed at increasing foreign demand (such as searches for foreign buyers and maintaining existing relationships with current buyers), in response to export market entry. Such demand-related investments have very similar effects to innovation, except that their returns only affect export profits, as opposed to overall profits. Chaney (2011) models the growth of exporters as they meet foreign importers in international social networks. ${ }^{6}$ There are also a number of recent papers featuring models of firm dynamics driven by frictional labor markets. See, e.g., Cosar et al (2011), Cosar (2011), Dix-Carneiro (2010), Fajgelbaum (2010), and Kambourov (2009). These models can generate slow transitions from trade liberalization as workers reallocate across firms and sectors.

Empirical work using micro-level data has confirmed the importance of dynamics in explaining firm export behavior. This behavior is also reflected in aggregate export patterns: new exporters initially account for a small proportion of aggregate exports, but those exporters grow faster than both established exporters and non-exporters, and they account for a substantial portion of aggregate export growth over longer periods of time (Over 40\% for the U.S. export growth from 1987 to 1992, and over 50\% for the export growth in both Colombia and Morocco from 1984 to 1991; See Bernard and Jensen (2004a) and Roberts and Tybout (1997).) Hysteresis effects are one major driver of those aggregate export dynamics: past export experience explains a very large proportion of a firm's current and future export performance, even after controlling for all observable firm performance indicators. ${ }^{7}$ This type of hysteresis behavior is explained by a combination of sunk export costs and firm level uncertainty (some form of stochastic firm dynamics, which could just be generated by shocks exogenous to the firm). Das, Roberts, and Tybout (2007) econometrically measure sizable sunk export costs for Colombian exporters, which induce effects of firms' expec-

\footnotetext{
${ }^{5}$ Foster, Haltiwanger, and Syverson (2010) document the importance of demand accumulation in accounting for U.S. plant dynamics in a number of U.S. manufacturing sectors.

${ }^{6}$ Drozd and Nosal (Forthcoming) present a macroeconomic model of customer accumulation to account for salient features of international relative prices and the dynamics of aggregate trade flows. Alessandria, Kaboski, and Midrigan (2010) present a model of trade and inventory management to account for the dynamics of aggregate trade flows and prices in the aftermath of loarge devaluations.

${ }^{7}$ See Roberts and Tybout (1997) for evidence in Colombia, Bernard and Wagner (2001) for Germany, and Bernard and Jensen (2004b) for the U.S.
} 
tations regarding future export market conditions on current export behavior. Ruhl (2008) shows that this combination of sunk export costs and idiosyncratic firm uncertainty also explains how the elasticity of trade with respect to changes in trade costs or aggregate productivity can vary substantially depending on the perceived persistence of those changes. Bergin and Lin (2010) document another example where firms' expectations about the future aggregate trading environment induces noticeable changes in the firms' current export market entry decisions. They show that European firms enter export markets prior to the implementation of EMU (and the associated decreases in trading frictions).

Another driver of the rapid export growth by new exporters is the link between export market entry and firm innovation. Many recent papers using micro-level have documented this link: Lileeva and Trefler (2009) for Canada, Verhoogen (2009) for Mexico, Bustos (2011) for Argentina, and Aw, Roberts, and Xu (Forthcoming) for Taiwan: ${ }^{8}$ They all find that a firm's export market entry (driven by reductions in trade costs) is associated with increased innovation. Bloom, Draca and Van Reenen (2008) also document a similar relationship between changes in the trading environment and firm innovation and skill upgrading, but on the import competition side: Firms in European industries most exposed to increased import competition from China respond by increasing their innovation and information technology intensity. ${ }^{9}$

\section{Model Economy}

In this Section we present our model of trade liberalization and firm dynamics. Time is discrete, and each period is labeled $t=0,1,2, \ldots$ We do not model any aggregate uncertainty. The economy has two symmetric countries: home and foreign; foreign variables are denoted with an asterisk superscript. Given the symmetry across countries, we only focus on the variables relevant for the home country. Households inelastically supply $L$ units of labor and derive utility from consumption only. Production in each country is structured as follows. There is a final non-traded consumption good that is produced using a continuum of differentiated intermediate goods with a constant returns to scale C.E.S. technology with elasticity of substitution $\rho>1^{10}$ These intermediate

\footnotetext{
${ }^{8}$ There is also another strand of the empirical literature that has documented a reduced form relationship between export market entry and subsequent firm productivity growth (often labeled as learning by exporting). See Greenaway and Kneller (2007) and Lopez (2005) for recent surveys.

${ }^{9}$ Bernard, Jensen, and Schott (2006) document a similar effect for import competition on the capital and skill intensity of the affected U.S. firms (increases in competition from low wage exporters associated with increases in both capital and skill intensity).

${ }^{10} \mathrm{By}$ assuming a demand structure with constant markups, we do not allowed for strategic considerations in pricing. This could generate some interesting implications for different returns to innovation across firms (see e.g. Aghion et
} 
goods can be internationally traded subject to fixed and variable trade costs. Firm productivity in the intermediate good sector is endogenously determined by a firm's choice regarding innovation intensity. Firm entry and exit is endogenous, and determines the aggregate measure of intermediate goods available in each country.

A firm in the home country with state $z$ has productivity equal to $\exp (z)^{1 /(\rho-1)}$ and produces output $y_{t}(z)$ with labor $l_{t}(z)$ according to the constant returns to scale production technology: ${ }^{11}$

$$
y_{t}(z)=\exp (z)^{1 /(\rho-1)} l_{t}(z)
$$

In addition, every operating firm must pay an overhead fixed cost equal to $f$ units of labor in every period. We re-scale firm productivity using the exponent $1 /(\rho-1)$ for expositional convenience: As we explain below, this re-scales a firm's size, variable profits and production employment (net of the overhead cost) to be proportional to $\exp (z)$.

Differentiated intermediate goods produced in home can be used for domestic production of the final good, or exported to foreign for use in foreign's final good production. Let $a_{t}(z)$ denote the domestic absorption of firm $z$ 's production. Similarly, let $a_{t}^{*}(z)$ denote the quantity of firm $z$ 's production used in foreign's final good production. Exports by firm $z$ incur both a fixed cost $f_{X}$ (measured in units of domestic labor) as well as a per-unit cost. The latter takes the form of an iceberg cost equal to $\tau-1$ units for each unit of the good exported (with $\tau \geq 1$ ). Due to the fixed export cost, it is unprofitable for some firms to export. Let $x_{t}(z) \in\{0,1\}$ denote the export indicator for firm $z$ at home $\left(x_{t}=1\right.$ if the firm exports and 0 otherwise). Feasibility requires

$$
a_{t}(z)+x_{t}(z) \tau a_{t}^{*}(z)=y_{t}(z)
$$

A firm in the foreign country with state $z$ has the same production technology as the home firm, but with output denoted $y_{t}^{*}(z)$, production labor $l_{t}^{*}(z)$, and domestic absorption $b_{t}^{*}(z)$. Exports to the home country, $b_{t}(z)$, are subject to both fixed and per-unit costs; hence, feasibility requires that $x_{t}^{*}(z) \tau b_{t}(z)+b_{t}^{*}(z)=y_{t}^{*}(z)$ and that $f_{X}$ units of foreign labor be used to pay the fixed export

${ }^{11}$ Since we do not make any assumptions regarding physical quantity units for the differentiated intermediate goods, firm productivity in that sector can be directly re-interpreted as product quality. In this alternative variant, firms innovate to improve product quality rather than productivity. This re-interpretation does not change any of our findings. Our model can also be extended to include other forms of physical and human capital as variable factors of production. Consideration of these forms of capital would lead to the standard amplification of the impact of a change in productivity on aggregate output.
} 
cost for all foreign exporting firms (with $\left.x_{t}^{*}(z)=1\right) .{ }^{12}$

The constant returns to scale C.E.S. production technology for the final good implies that the total quantity of the good produced at home is given by

$$
Y_{t}=\left[\int a_{t}(z)^{1-1 / \rho} M_{t}(z) \mathrm{d} z+\int x_{t}^{*}(z) b_{t}(z)^{1-1 / \rho} M_{t}^{*}(z) \mathrm{d} z\right]^{\rho /(\rho-1)}
$$

where $M_{t}(z)$ is the distribution of operating firms in the home country over the productivity index $z$, and $M_{t}^{*}$ the corresponding distribution in the foreign country. The total measure of operating firms in the home country is given by $\int M_{t}(z) \mathrm{d} z$. Production of the final good in the foreign country, $Y_{t}^{*}$, is defined analogously.

The final good sector in both countries is competitive. Let $P_{t}$ denote the final good price in home, and $p_{a t}(z)$ and $p_{b t}(z)$ the prices of the domestic and imported intermediate goods in the home country. We pick labor as the numeraire good, and normalize the wage to 1 . Final good producers take these prices as given; they also take all the decisions by the intermediate good firms (that determine $\left.x_{t}(z), x_{t}^{*}(z), M_{t}(z), M_{t}^{*}(z)\right)$ as given. The final good price is thus given by its unit cost:

$$
P_{t}=\left[\int p_{a t}(z)^{1-\rho} M_{t}(z) \mathrm{d} z+\int x_{t}^{*}(z) p_{b t}(z)^{1-\rho} M_{t}^{*}(z) \mathrm{d} z\right]^{1 /(1-\rho)} .
$$

The demand for the intermediate goods at home is then given by:

$$
\frac{a_{t}(z)}{Y_{t}}=\left(\frac{p_{a t}(z)}{P_{t}}\right)^{-\rho} \text { and } \frac{b_{t}(z)}{Y_{t}}=\left(\frac{p_{b t}(z)}{P_{t}}\right)^{-\rho}
$$

Analogous equations hold for prices and quantities in the foreign country.

Intermediate good firms in each country are monopolistically competitive. A home firm with productivity index $z$ faces a static profit maximization problem involving the choice of labor input $l_{t}(z)$, prices $p_{a t}(z), p_{a t}^{*}(z)$, quantities $a_{t}(z), a_{t}^{*}(z)$, and an export decision $x_{t}(z)$. In so doing, the firms take as given the prices and quantities of the final good in both countries (recall that the wage is normalized to 1). Firm z's profit maximization problem is:

$$
\Pi_{t}(z)=\max _{\substack{y_{t}(z), l_{t}(z), p_{a t}(z), p_{a t}^{*}(z), a_{t}(z), a_{t}^{*}(z), x_{t}(z)}} p_{a t}(z) a_{t}(z)+x_{t}(z) p_{a t}^{*}(z) a_{t}^{*}(z)-l_{t}(z)-x_{t}(z) f_{X}
$$

subject to (1), (2), and (5). We define $\bar{z}_{X t}$ as the export productivity cutoff: $\bar{z}_{X t} \equiv \arg \min \left\{x_{t}(z)=1\right\}$.

\footnotetext{
${ }^{12}$ Symmetry between home and foreign implies that $y_{t}(z)=y_{t}^{*}(z), x_{t}(z)=x_{t}^{*}(z), a_{t}(z)=b_{t}^{*}(z), a_{t}^{*}(z)=b_{t}(z)$.
} 
We now describe the productivity dynamics of individual firms. At the beginning of each period $t$, every existing firm faces an exogenous probability $\delta$ of incurring a "death" shock that would induce exit (exogenous exit unconditional on productivity). The remaining $1-\delta$ portion of firms can still choose to exit (endogenous exit conditional on productivity) or to continue to operate and pay the overhead cost $f$. Productivity for those firms then evolves over time depending on the their investment in innovation, which stochastically improves productivity. We model the evolution of productivity for producing firms as follows: In the following period $(t+1)$, a firm with productivity index $z$ has a probability $q$ of having productivity $\exp \left(z+\Delta_{z}\right)^{1 /(\rho-1)}$ and a probability $1-q$ of having productivity $\exp \left(z-\Delta_{z}\right)^{1 /(\rho-1)}$. Hence, the expected growth of $z$ is given by $(2 q-1) \Delta_{z} \cdot{ }^{13}$ We will examine a special case where $\Delta_{z}=0$, so that productivity is constant throughout a firm's life; this is the case with no productivity dynamics.

In the specification of our model with endogenous innovation, each firm invests in innovation by choosing the expected growth of their current productivity $z$ (determined by $q$ ). A firm with productivity $z$ choosing an innovation intensity $q$ must hire $\exp (z) c(q)$ units of labor as its investment in innovation. We assume that $c(q)$ is increasing and convex in $q$.

With this evolution of firm productivity, the expected, discounted present value of profits (abstracting from aggregate uncertainty) for a firm with initial productivity index $z$ is

$$
V_{t}(z)=\max \left[0, V_{t}^{o}(z)\right]
$$

where the value for operating firms is given by the following Bellman equation:

$$
V_{t}^{o}(z)=\max _{q \in[0,1]} \Pi_{t}(z)-\exp (z) c(q)-f+(1-\delta) \frac{1}{R_{t}}\left[q V_{t+1}\left(z+\Delta_{z}\right)+(1-q) V_{t+1}\left(z-\Delta_{z}\right)\right]
$$

$R_{t}$ is the world interest rate in period $t$ (in units of labor). Let $q_{t}(z)$ denote the optimal innovation intensity of the firm referenced in (8). This choice of innovation intensity must satisfy the first order condition:

$$
\exp (z) c^{\prime}(q)=(1-\delta) \frac{1}{R_{t}}\left[V_{t+1}\left(z+\Delta_{z}\right)-V_{t+1}\left(z-\Delta_{z}\right)\right]
$$

Note that with our scaling of the innovation cost function, $\exp (z)$, we are assuming that the innovation cost required to increase the size of the firm by a fixed percentage scales with the size of the firm. This will imply that, for sufficiently large firms, the innovation decision and derived

\footnotetext{
${ }^{13}$ Note also that if the time period is small, then our binomial productivity process approximates a geometric Brownian motion in continuous time, as in the work of Luttmer (2007).
} 
growth rate is independent of size, consistent with Gibrat's law, and the firm size distribution has a Pareto right-tail. We denote by $\bar{q}_{t}$ the innovation intensity for such very large firms, i.e. $\bar{q}_{t}=\lim _{z \rightarrow \infty} q_{t}(z)$.

In our quantitative analysis, we assume that the innovation cost function has the form $c(q)=$ $h \exp (b q)$, so that the curvature of this function is indexed by the parameter $b$. If this curvature parameter $b$ is high (or low), then innovation is highly inelastic (or elastic) to changes in the incentives to innovate. With a very high curvature parameter $b$, innovation decisions of firms are effectively constant both across firms and over time, $q_{t}(z)=\bar{q}$. This is the exogenous innovation case.

Since the value function of operating firms $V_{t}^{0}(z)$ is strictly increasing in $z$, the endogenous exit or operate decision (7) must follow a cutoff rule: firms with productivity at or above a cutoff $\bar{z}_{t}$ choose to operate, while the remaining firms choose the exit option. Note that if $f=0$, then $V_{t}^{o}(z)=V_{t}(z)$ and $\bar{z}_{t}=-\infty$; hence, there is no endogenous exit.

New firms are created with an investment of $f_{E}$ units of labor, which yields a new firm in the following period with initial productivity index $z$ drawn from a distribution $G(z)$. In any period in which new firms enter, free entry requires that

$$
f_{E}=\frac{1}{R_{t}} \int V_{t+1}(z) G(z) \mathrm{d} z
$$

Let $M_{E t}$ denote the measure of new firms entering in period $t$ that start producing in period $t+1$.

Households in the home country have preferences of the form $\sum_{t=0}^{\infty} \beta^{t} \log \left(C_{t}\right)$, where $C_{t}$ is their consumption of the home final good in period $t$ and $\beta \leq 1$ is their discount factor. Each household in the home country faces an intertemporal budget constraint of the form

$$
\sum_{t=0}^{\infty}\left(\prod_{j=0}^{t} \frac{1}{R_{j-1}}\right)\left(P_{t} C_{t}-L\right) \leq \int V_{0}(z) M_{0}(z) \mathrm{d} z
$$

with $R_{-1}=1$. In writing the budget constraint (11) we have assumed that the free-entry condition holds with equality in every period and that the representative consumer in each country owns only the firms in their respective countries. The right hand side thus represents the initial home consumer wealth from the existing stock of home firms in period 0 .

With balanced trade (which is immediate with symmetric countries), production and consumption of the final good are equalized in every period: $C_{t}=Y_{t}$. Without loss of generality, we 
normalize aggregate labor supply to 1 . This labor is used for production of intermediate goods $\left(L_{P t}\right)$, innovation $\left(L_{I t}\right)$, and to cover the fixed costs for entry, overhead production, and export: ${ }^{14}$

$$
L_{P t}+L_{I t}+M_{E t} f_{E}+\int\left[f+x_{t}(z) f_{X}\right] M_{t}(z) \mathrm{d} z=1
$$

where

$$
L_{P t}=\int l_{t}(z) M_{t}(z) \mathrm{d} z \text { and } L_{I t}=\int\left[\exp (z) c\left(q_{t}(z)\right)\right] M_{t}(z) \mathrm{d} z .
$$

The evolution of the distribution of operating firms $M_{t}$ over time is given by the exogenous probability of exit $\delta$, the decisions of operating firms to invest in their productivity $q_{t}(z)$, and the measure of entering firms in period $t, M_{E t}$. The distribution of operating firms $M_{t+1}\left(z^{\prime}\right)$ in the home country in period $t+1$ is equal to the sum of three inflows of firms: new firms that entered in period $t$, firms continuing from period $t$ that draw positive productivity shocks (and, hence, had productivity equal to $z^{\prime}-\Delta_{z}$ in period $t$ ), and firms continuing from period $t$ that draw negative productivity shocks (and, hence, had productivity equal to $z^{\prime}+\Delta_{z}$ in period $t$ ). We write this as follows:

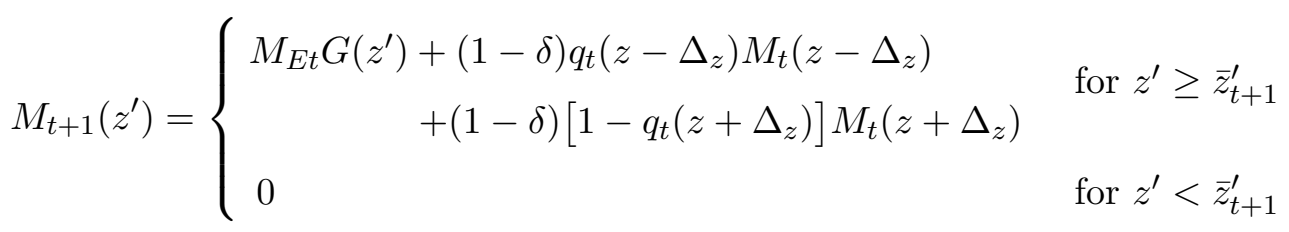

An equilibrium in this economy is a collection of sequences of aggregate prices $\left\{R_{t}, P_{t}, P_{t}^{*}\right\}$ and prices for intermediate goods $\left\{p_{a t}(z), p_{a t}^{*}(z), p_{b t}(z), p_{b t}^{*}(z)\right\}$, a collection of sequences of aggregate quantities $\left\{Y_{t}, Y_{t}^{*}, C_{t}, C_{t}^{*}, L_{P t}, L_{P t}^{*}, L_{I t}, L_{I t}^{*}\right\}$ and quantities of the intermediate goods $\left\{a_{t}(z)\right.$, $\left.a_{t}^{*}(z), b_{t}(z), b_{t}^{*}(z), l_{t}(z), l_{t}^{*}(z)\right\}$, and a collection of sequences of firm value functions and profit, exit, export, and innovation decisions $\left\{V_{t}(z), V_{t}^{*}(z), V_{t}^{o}(z), V_{t}^{o *}(z), \Pi_{t}(s), \Pi_{t}^{*}(s), \bar{z}, \bar{z}^{*}, x_{t}(z)\right.$, $\left.x_{t}^{*}(z), q_{t}(z), q_{t}^{*}(z)\right\}$ together with distributions of operating firms and measures of entering firms $\left\{M_{t}, M_{E t}, M_{t}^{*}, M_{E t}^{*}\right\}$ such that households in each country maximize their utility subject to their budget constraints, intermediate good firms in each country maximize the net present value of their per-period profits, final good firms in each country maximize profits, all of the feasibility constraints are satisfied, and the distribution of operating firms evolve as described above.

As we previously mentioned, we focus our analysis on symmetric equilibria across countries. To

\footnotetext{
${ }^{14}$ Note that, by assuming that fixed costs and innovation costs are incurred in terms of labor only, we are assuming that $\lambda=1$ in the more general formulation of Atkeson and Burstein (2010).
} 
ensure this symmetry, we assume that the initial distribution of firms is identical across countries: $M_{0}(z)=M_{0}^{*}(z)$. This also ensures equality of initial wealth for home and foreign consumers. The symmetry between home and foreign will then be preserved in every subsequent period. Thus, all the home country variables that we have introduced will be equal to their foreign country counterpart.

A steady state of our model is an equilibrium in which all of the aggregate variables are constant. In what follows, we omit time subscripts when discussing the steady state. ${ }^{15}$ Depending on parameter values, there are two types of steady states in our model: one with entry and one without entry. The parameter restrictions required to have a steady-state with entry imply that the equilibrium innovation decision of large firms leads them to shrink in expectation. ${ }^{16}$ Our results are derived in the case in which every period there is positive firm entry.

\section{Aggregation in a Symmetric Equilibrium}

The equilibrium of our model with heterogeneous firms and endogenous innovation cannot be fully solved in closed-form. Appendix A describes a simple algorithm to solve for the symmetric steadystate. The online appendix of Atkeson and Burstein (2010) describes an algorithm to solve for the transition dynamics across steady-states. We now present some aggregate relations that hold in a symmetric equilibrium of our model that we use in our analytic results. We also define aggregate statistics that we report from our experiments.

The solution to the static profit maximization problem (6) in a symmetric equilibrium is

$$
\Pi_{t}(z)=\Pi_{D t} \exp (z)+\max \left(\Pi_{D t} \tau^{1-\rho} \exp (z)-f_{X}, 0\right)
$$

where $\Pi_{D t}$ is a domestic market demand index given by

$$
\Pi_{D t}=\frac{P_{t}^{\rho} Y_{t}}{\rho^{\rho}(\rho-1)^{1-\rho}}
$$

\footnotetext{
${ }^{15}$ See Atkeson and Burstein (2011) for a detailed discussion of how a similar model of innovation by firms in a closed economy can be extended to allow for endogenous and semi-endogenous growth.

${ }^{16} \mathrm{~A}$ sufficient condition to obtain a steady state with entry is that $\lim _{z \rightarrow \infty}(1 \quad-$

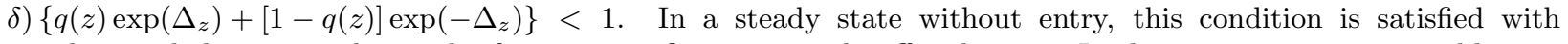
equality, and the expected growth of continuing firms is exactly offset by exit. In this case, aggregate variables are constant but the distribution of firms by size is not as production becomes concentrated in a shrinking number of large firms.
} 
This market demand index also proportionally scales production employment for all firms:

$$
l_{t}(z)=(\rho-1) \Pi_{D t}\left[1+x_{t}(z) \tau^{1-\rho}\right] \exp (z)
$$

Given that firm revenues are proportional to firm employment, the ratio of exports to the aggregate value of production (for the intermediate goods sector) is given by

$$
s_{X t}=\frac{\tau^{1-\rho} \int x_{t}(z) \exp (z) M_{t}(z) \mathrm{d} z}{\int \exp (z) M_{t}(z) \mathrm{d} z+\tau^{1-\rho} \int x_{t}(z) \exp (z) M_{t}(z) \mathrm{d} z} .
$$

Similarly, the ratio of exporters' revenues in the domestic market to total domestic revenues (the market share of exporters in their domestic market) is given by

$$
s_{D t}=\frac{\int x_{t}(z) \exp (z) M_{t}(z) \mathrm{d} z}{\int \exp (z) M_{t}(z) \mathrm{d} z}
$$

This share of exporters in the domestic market differs from the share of exporters in total production in that it does not capture the direct impact of changes in trade costs on the size of exporters, but instead just reflects the reallocation of production between non-exporters and exporters in the domestic market.

Aggregating (16) across firms, and using the expression for the aggregate price (4), we can express aggregate output $Y_{t}$ as

$$
Y_{t}=Z_{t}^{\frac{1}{\rho-1}} L_{P t}
$$

where

$$
Z_{t}=\int\left[1+\tau^{1-\rho} x_{t}(z)\right] \exp (z) M_{t}(z) \mathrm{d} z
$$

is an index of aggregate productivity. Average productivity for domestic production is given by

$$
\bar{Z}_{t}=\frac{\int \exp (z) M_{t}(z) \mathrm{d} z}{\int M_{t}(z) \mathrm{d} z}
$$

Since firm size on the domestic market is proportional to $\exp (z)$, this average productivity index is also proportional to the average firm size on the domestic market. Put another way, for a given level of market demand $\Pi_{D t}$, changes in average productivity $\bar{Z}_{t}$ are proportional to changes in average firm size on the domestic market. 


\section{Baseline parameterization}

To understand our model's aggregate dynamics to trade liberalizations, we present both analytic and computational results. The latter are based on a calibration of the model that follows Atkeson and Burstein (2010). Here we present an overview of this calibration, which is designed to target a number of salient features of U.S. data on firm dynamics, the firm size distribution, and international trade. We refer the reader to Atkeson and Burstein (2010) for further details.

The parameters that we must choose are the steady-state real interest rate $R=1 / \beta$, the distribution $G$ of productivity draws of entrants, the parameters governing the variance of employment growth for surviving firms $\Delta_{z}$, the exogenous exit rate of firms $\delta$, the marginal trade $\operatorname{costs} \tau$, the fixed costs of operation $f$ and entry $f_{E}$, the fixed costs of exporting $f_{X}$, the parameters of the innovation cost function $h$ and $b$, and the elasticity of substitution across intermediate goods in final output $\rho$.

Table 1 summarizes the targets and parameter values used in our baseline parameterization. We consider two choices of the curvature parameter $b$ for the innovation cost function: one where $b$ is sufficiently high that the innovation decision is effectively inelastic across firms and over time $\left(q_{t}(z)=\bar{q}\right)$, and another where $b=10$ so that innovation decisions are quite elastic across firms and over time. We set $\beta$ such that the steady-state interest rate (annualized) is 5 percent, and $\rho=5$ consistent with estimates by Broda and Weinstein (2005). We choose the distribution $G$ of productivity draws of entrants so that all firms enter with a common productivity index $z=0$ (the cross-sectional distribution of $z$ is then determined by the ergodic distribution generated by the productivity dynamics). We choose $\Delta_{z}$ to match the standard deviation of the growth rate of employment of large US firms. We choose the exogenous exit rate $\delta$ to match the annual employment-weighted exit rate of large US firms. We normalize entry costs $f_{E}=1$, and we set

the fixed costs of operation $f=0.1$. We choose the parameters $f_{X}, \tau^{1-\rho}$, and $h$ to match three observations in the U.S.: (1) the fraction of exports in gross output; (2) the fraction of total production employment accounted for by exporting firms; and (3) the shape of the right tail of the firm size distribution.

\section{$5 \quad$ Trade Liberalization Scenarios}

We restrict our analysis of trade liberalization to decreases in the per-unit trade $\operatorname{cost} \tau$. Throughout all scenarios, we consider the effects of a $3.5 \%$ reduction in $\tau$, starting from the calibrated steady 
state described above. ${ }^{17}$ We consider the following experiments. We first consider the effects of a permanent unanticipated reduction in the trade cost, and describe how firm productivity dynamics interact with endogenous export market selection to generate endogenous aggregate transition dynamics. We then examine the role of anticipated changes in trade policy. We first look at the case where that same unanticipated drop in the trade cost is anticipated to revert back to the old steady state (so the trade liberalization is only temporary). We then look at the case where the initial trade liberalization is anticipated (and permanent thereafter). We present our computational results graphically, using figures that show the responses over time of key variables for the economy. In several cases, we also complement these numerical results with analytical propositions regarding those dynamic responses (the proofs are relegated to the appendix).

In order to highlight the key interactions between firm productivity dynamics and endogenous export market selection, we start with two scenarios that exhibit only one of those features at a time (eliminating the other). Our first scenario eliminates endogenous market selection (all firms export), while our second one eliminates firm productivity dynamics (firm productivity remains constant post entry). In both those cases, we show that permanent trade liberalization does not induce any endogenous transition dynamics. In order to motivate how firm productivity dynamics and endogenous export market selection interact to generate transition dynamics, we develop a simplified analytical variant of our model that nevertheless exhibits both of those features. This analytical model clarifies how differences in current and future export market profitability (relative to the profitability of domestic sales) drives transition dynamics in response to a sudden, permanent trade liberalization (via its effect on firm entry). In our third scenario we show that these analytic results carry over to our full model with exogenous innovation. In our fourth scenario, we add endogenous innovation and describe its effect on the transition dynamics - contrasting them to our previous scenario where innovation is exogenous. In our fifth scenario, we examine the case of a temporary trade liberalization. We show how expectations regarding the permanence of trade liberalization affect the response of innovation. Lastly, we study the effects of an anticipated trade liberalization. We return to the case of a permanent decrease in trade costs, but we now assume that this decrease in trade cost is anticipated (ahead of any change in the trade cost). Scenario six captures those anticipation effects and shows how they are much more pronounced when innovation is endogenous (relative to the exogenous innovation case). Our seventh and eight scenarios add

\footnotetext{
${ }^{17}$ We choose this change in trade cost to ensure that our model with endogenous innovation produces a steady state with entry (with very large changes in trade costs, the increase in the growth rate of exporting firms induces a non-stationary firm size distribution).
} 
sunk export market costs, thus introducing partial irreversibility and option values associated to the export entry decisions. We show how the perceived permanence of the trade liberalization shapes the strength of entry into exporting, and how anticipated trade liberalization affects the option values from entry into exporting and induces transition dynamics ahead of the actual drop in the trade cost.

\section{Scenario 1: No Export Market Selection}

In this scenario, we start with our baseline model but eliminate export market selection by setting the fixed export cost to zero, $f_{X}=0$ (all firms export regardless of their productivity $z$ ). The responses of the key variables of the model are depicted in Figure 1. Panel A reports the time path of the exogenous per-unit trade cost $\tau$ as a percentage of the old steady state, $\tau_{t} / \tau_{0}(96.5 \%$, reflecting the permanent 3.5\% decrease in $\tau$ ). Panels B-F report the other responses in elasticity format: $\log \left(X_{t} / X_{0}\right) / \log \left(\tau_{t} / \tau_{0}\right)$ for each variable $X$. Thus, those responses depict the percentage change in $X$ per $1 \%$ change in $\tau$. Panel $\mathrm{B}$ depicts the response of final output $Y_{t}$ (equal to aggregate consumption $C_{t}$ ) and production labor $L_{P t}$; Panel $\mathrm{C}$ depicts the response of entry $M_{E t}$; Panel D depicts the response of average productivity for domestic production $\bar{Z}_{t}$; Panel E depicts the response of the revenue share of exporters in domestic revenues, $s_{D t}$, and in total revenues, $s_{X t}$; Panel F depicts the response of the innovation intensity $q_{t}$ for large firms (technically, $\lim _{z \rightarrow \infty} q_{t}(z)$ ).

As is apparent from those responses in Figure 1, the permanent trade liberalization does not induce any transition dynamics. Final output jumps up to its new steady state level, along with the share of exports in total revenues. The change in the trade cost does not induce any further reallocations: the intensity of innovation, exit threshold (not shown in the figure), entry, and production labor remain unchanged, hence there are no composition effects across firms (no change in average productivity $\bar{Z}_{t}$ ). The economy's response to the lower trade $\operatorname{cost} \tau<\tau_{0}$ is identical to the response in Krugman's (1980) model with representative firms: all firms reallocate their production towards export sales without varying total employment; there is no change in firm entry or exit; and final output (consumption) rises only due to the direct effect of the change in the trade cost (fewer units of output "melt" away). Proposition 1 in Appendix B derives these results analytically, and shows that the proportional increase in final output is

$$
\frac{Y}{Y_{0}}=\left(\frac{1+\tau^{1-\rho}}{1+\tau_{0}^{1-\rho}}\right)^{\frac{1}{\rho-1}}
$$


This is the same rise in final output as in an Armington world where every country produces a single good with exogenous unit labor requirements. The main intuition for the absence of any inter-firm reallocation or change in innovation is that, in a world with C.E.S. demand and constant markups, the increased export opportunities from lower trade costs are exactly offset by the reductions in domestic sales (driven by increased imports). All firms face those same exact trade-offs, and there is thus no scope for any inter-firm reallocations, and no motive for any change in innovation decisions. The expected value of an entering firm relative to the entry cost is unchanged, and there is hence no change in entry behavior. ${ }^{18}$

\section{Scenario 2: No Firm Productivity Dynamics}

We now allow for export market selection (the fixed cost $f_{X}>0$ is calibrated to match the aggregate export patterns described above), but eliminate firm productivity dynamics. This is equivalent to setting $\Delta_{z}=0$. In order to match the right tail of the firm-size distribution of the model with firm dynamics, we assume that the initial firm productivity is drawn at entry from a Pareto distribution $G$ with shape parameter $\theta>\rho-1$.

The responses of the same key variables are depicted in Figure 2. Here too, we see that the permanent trade liberalization does not induce any endogenous transition dynamics. As in the previous scenario, there is no response in entry, and final output (consumption) immediately jumps to its new steady state level. However, this scenario does feature some inter-firm reallocation. The lower trade cost induces high productivity firms to become exporters. Firms with low productivity cannot take advantage of the increased export opportunities, and thus disproportionately suffer from the reductions in domestic sales. This induces the exit of the least productive firms, and labor is reallocated from non-exporters and exiters towards exporters. The expansion of the exporters relative to the non-exporters and exiters induces an increase in average firm productivity (Panel D). Panel E shows how this expansion of exporters relative to non-exporters is reflected in the increased share of exporters in domestic revenues (which was flat in the previous scenario with no inter-firm reallocations). The response of the share of exporters in total revenues is now higher (relative to the previous scenario) due to the effects of the lower trade cost on the extensive margin of trade (new exporters). ${ }^{19}$

\footnotetext{
${ }^{18}$ If the cost of entry falls (for instance, if entry cost required both labor and final output), then entry rises, giving rise to endogenous transition dynamics across steady-states. All other results still hold (e.g. innovation and exit thresholds remain unchanged). Similarly, if innovation requires both labor and final output, innovation rises for all firms, giving rise to endogenous transition dynamics.

${ }^{19}$ In an alternative calibration, in which $\theta$ is chosen to be equal to $\rho-1$, the trade elasticities in scenarios 1 and 2
} 
This scenario features the same inter-firm reallocations that would be observed in a static model of trade liberalization. In our dynamic version, those reallocations all take place immediately upon the decline in trade costs. A key feature driving this result is that trade liberalization does not affect the incentives for entry. The exit and export market cutoffs then jump immediately to their steady state levels, and there are no ensuing transition dynamics. We detail these results in Proposition 2 in Appendix C, but note here that this result for entry is a dynamic version of the result derived by Arkolakis et al (2010). In both cases, this result is driven by offsetting effects of lower trade costs on an entrant's expected profits. On one hand, the lower trade cost increases the profitability of large exporters (high $z$ ); on the other, it also reduces the profitability of small firms (low $z$ ). The exact offsetting of these two forces is naturally very specific to the assumed parametrization (especially, C.E.S. demand and Pareto distribution for firm productivity).

\section{Firm Dynamics and the Effect of Trade Liberalization on Entry: Building Intuition}

We now show that, adding firm productivity dynamics completely changes the trade-offs described above for the effects of trade liberalization on entry. We first build a simplified (and slightly modified) version of our model that motivates a simple analytic rule governing this trade-off. This rule is not tied to a specific parametrization, and allows us to predict the response of entry to trade liberalization for more general cases. We then show how it applies to our full model with both endogenous export market selection and firm productivity dynamics.

Consider the following version of our model that allows for time variation in the fixed export cost $f_{X}$. In particular, $f_{X}=\infty$ if the firm has entered $T \geq 0$ or less periods ago, and $f_{X}=0$ if the firm has entered $T+1$ or more periods ago. Hence, conditional on survival, firms start exporting after $T$ periods of operation. Note that if $T=0$, all firms export. We also assume that all entering firms have productivity index $z=0$, there are no productivity dynamics $\left(\Delta_{z}=0\right)$, and there are no fixed overhead costs, $f=0$ (so exit takes place due to exogenous death only).

We denote by $\tilde{s}_{X}$ the ratio of discounted time-series revenues from exports in total discounted time-series revenues of entering firms. That is, while $s_{X}$ measures the export share in the crosssection of firms, $\tilde{s}_{X}$ measures the export share in the discounted revenues of entering firms. ${ }^{20}$ If $\beta=1$, then $\tilde{s}_{X}=s_{X}$; If $\beta<1$ and $T>0$, then exporters are back-loaded so $\tilde{s}_{X}<s_{X}$. More generally, if $\beta<1$, then as $T$ rises (so that it takes longer for an entrant to become an exporter),

would be equal, while our other qualitative results remain unchanged.

${ }^{20} \tilde{s}_{X}$ is calculated analogously to the export share $s_{X}$ using (17), with a "discounted" distribution of firms $\tilde{M}(z)$ that is defined analogously to $M(z)$ in $(13)$ - except that $\beta(1-\delta)$ replaces $(1-\delta)$ and $\beta G(z)$ replaces $G(z)$. 
profits from exporting become a less important component of a firm's value upon entry, and $\tilde{s}_{X}$ falls relative to $s_{X}$.

Proposition 3 in Appendix D states that in this economy, a permanent reduction in marginal trade costs, $\tau$, leads to a decline (increase) in the steady-state mass of entering firms, $M_{E}$, if and only if $\tilde{s}_{X}$ is strictly lower (higher) than $s_{X}$, and the steady-state mass of entering firms remains unchanged if and only if $\tilde{s}_{X}=s_{X}$. The intuition for this result is straightforward. When $\tilde{s}_{X}<s_{X}$, incumbent exporting firms benefit proportionally more than entering non-exporting firms from lower trade costs. Hence, trade liberalization makes entry less profitable, and entry falls. This result suggests that the relative size of entering firms plays an important role in shaping the change in entry and the aggregate transition dynamics in response to a trade liberalization. ${ }^{21}$

We now apply this logic to understand the response of entry and aggregate transition dynamics in our full model with productivity dynamics.

\section{Scenario 3: Export Market Selection and Firm Dynamics with Exogenous Innovation}

We now return to our baseline model with both endogenous export market selection and firm productivity dynamics. In this scenario, we assume that the parameter $b$ of the innovation cost function is sufficiently high so that innovation intensity is constant across firms and over time: $q_{t}(z)=\bar{q}$. This is the exogenous innovation case. The Markov evolution process for firm productivity is such that entering firms are, on average, smaller than incumbents - and are thus less likely to export than incumbents. ${ }^{22}$ This implies that, with $\beta<1, \tilde{s}_{X}<s_{X}$ from our previous analytical model.

The responses of the same set of variables for this scenario are depicted in Figure 3. A permanent trade liberalization makes entry less profitable as incumbent exporters benefit proportionally more than non-exporting entrants. As we see from panel C, entry responds as our simple analytic model suggests: it drops upon the reduction of the trade costs. Because the new steady state with lower trade costs features a smaller mass of producing firms (due to the smaller mass of entrants in steady-state), there is an "overhang" of incumbent firms immediately after trade liberalization. This leads to an overshooting of the entry response as the mass of producing slowly decreases to its new lower steady-state level. The labor resources that were previously allocated to entry are available for production employment. There is a spike in production employment (inversely

\footnotetext{
${ }^{21}$ Atkeson and Burstein (2010) extend this result to a more general setting for the structure of productivity and export participation dynamics. Fattal-Jaef (2010) presents a related result in a model of firm dynamics and misallocation distortions.

${ }^{22}$ This also matches the empirical regularity that most firms do not export immediately after entry.
} 
related to the downward spike in entry) and a similar spike in final output. Due to these transition dynamics, we see that comparing consumption across steady-states understates the welfare gains from liberalization that accrue during the transition as the mass of firms declines.

The reallocation of market share towards exporting firms leads to an increase in average firm productivity in the new steady state. Average productivity overshoots this new steady-state level over the transition due to the overshooting of entry (since entrants are relatively less productive). The transition dynamics for the fraction of exporters' revenues in total and domestic revenues are not very pronounced. They behave in a similar way as the previous scenario with no firm productivity dynamics.

In order to emphasize how the difference between the export profitability shares $\tilde{s}_{X}$ and $s_{X}$ drive the response of entry, Figure 4 contrasts the response of entry and final output under our baseline interest rate and a zero interest rate $(\beta=1)$. In the latter case, the delay for entrants to grow and start exporting becomes inconsequential; their future expected revenues from exporting $\tilde{s}_{X}$ is equal to the cross-sectional export share $s_{X}$. Figure 4 shows how, in this case, the response of entry becomes very muted, as do the transition dynamics for final output. Similarly, if the model is calibrated so that entering firms grow faster (and hence become exporters earlier), the decline in entry is also muted relative to our baseline parameterization.

\section{Scenario 4: Endogenous Export Market Selection and Endogenous Innovation}

We now switch to the more elastic parametrization for innovation. The economy's responses are reported in Figure 5. This is the first scenario to feature a response in firm innovation intensity to trade liberalization. This response is exhibited in Panel F for the innovation intensity of large exporting firms (all firms above a given large size threshold). As in the case with exogenous innovation, the permanently lower trade costs increase the value of exporters relative to nonexporters. In the current case, those exporters respond by innovating relatively more. In Appendix E we derive analytically this reallocation of innovation from non-exporters to exporters, and discuss how it depends on key model parameters.

The immediate response of entry is similar to the case of exogenous innovation (and for the same reasons: trade liberalization makes entry less profitable as entrants' exporting profits are pushed back into the future). Average firm size and productivity steadily increases (Panel D) from the combination of selection (reduced entry by smaller, less productive firms), and increased innovation by exporters. Although the response in increased innovation intensity is immediate, its 
effects on the productivity and size of exporters takes a long time to unfold. As the average size and productivity of exporters grow relative to those of entrants, the expected profitability for that latter group further falls, inducing a second dip in entry (Panel C). The increase in relative size and productivity of exporters also leads to a steadily increasing share of exporters in domestic and total revenue (Panel E). Hence, the elasticity of trade volumes to changes in trade costs is higher when it is calculated over longer time horizons.

The labor resources used for entry are reallocated to production (and some to the increased innovation activity). Production labor steadily rises, mirroring the decrease in entry (Panel B). Those changes in production labor are also reflected in a rise in final output. As opposed to the exogenous innovation case, steady state consumption now overstates the welfare gains from trade liberalization because the increase in average productivity takes many periods to materialize. The main message for welfare comparative statics remains that transition dynamics strongly affect any comparison based on steady state consumption.

We note that the increase of innovation to trade liberalization is not limited to current exporters: trade liberalization also spurs the innovation response of non-exporters who anticipate exporting in the future (given the lower trade costs). In fact, from equation (9), firms close to the export threshold have the biggest incentive to innovate, because they have the highest marginal benefit from successful innovation (i.e. the difference between profits as an exporter relative to profits from only serving the domestic market). We highlight this result in Figure 6, which shows the difference in innovation intensity, $\Delta q(z)$, across the two steady states (pre- and post-liberalization) as a function of $z$. In the figure, $z$ is reported as the difference relative to the exit threshold $\bar{z}_{X}$. The figure also shows the change across the two steady states in the export threshold. All exporters increase their innovation intensity $(\Delta q(z)>0)$, but firms around the export threshold both current exporters and non-exporters that anticipate to be exporters in the future - have the highest increase in innovation activity. Due to the increased competition from foreign producers and more productive domestic producers, a subset of firms with the lowest productivity (who have the smallest probability of becoming an exporters) innovate less in response to trade liberalization.

Figures 5 and 6 also highlight how firm productivity increases immediately following export market entry need not reflect learning by exporting: this observed empirical pattern may also reflect the outcome from the innovation activities undertaken by new exporters. 


\section{Scenario 5: Temporary Trade Liberalization}

In our last scenario, we saw how endogenous innovation can drastically affect the transition dynamics to trade liberalization - so long as the economy also features endogenous export market selection (recall the result from scenario 1 that endogenous innovation does not induce transition dynamics in the absence of endogenous export market selection). Those transition dynamics are driven by the response of innovation intensity by exporters and anticipated exporters (as well as the response of entry). In this scenario, we highlight one other crucial ingredient needed to deliver this innovation response: trade liberalization must be perceived to be long-lasting; otherwise, the incentives for innovation are strongly muted, because its benefits accrue slowly over time. This issue of perceived persistence for trade liberalization is empirically consequential, as it exhibits so much variation from one trade liberalization episode to another (both across countries and within countries across episodes). To highlight the role of this perceived persistence for innovation, our next scenario examines the case of a trade liberalization (same unanticipated $3.5 \%$ drop in trade cost) that is then gradually reversed within a 10 year period. The initial trade liberalization occurs as in our previous scenario: a sudden unanticipated 3.5\% drop in the per-unit trade cost. We assume that the trade cost remains at its "liberalized" level for 4 years, and then linearly reverts back to its pre-liberalization level over the following 5 years. This unwinding of trade liberalization is anticipated by firms immediately after the initial drop in the trade cost.

We focus on this 4 year period following the initial trade liberalization and contrast the innovation intensity response with the previous scenario, when trade liberalization was anticipated to be permanent (same assumptions regarding endogenous innovation process). Note that whatever actually happens to the trade cost after that 4 year window is not critical for our analysis within that time window. Trade liberalization may end up not being permanent when anticipated as such, and vice-versa. Within the 4 year window following trade liberalization, the only difference between the two scenarios is one of anticipation by firms regarding the permanence of the initial liberalization.

Figure 7 contrasts the innovation response for the permanent and temporary trade liberalization scenarios. Panel A shows the divergence in the path of the trade cost 4 years beyond the initial liberalization (but does not show the key difference in anticipation within the 4 year window). The anticipation effect for the innovation response is clearly visible in Panel B: the response of innovation when trade liberalization is anticipated to be temporary is strongly muted following the 
initial liberalization. Over that 4 year period, the lower increase in innovation intensity translates into significance differences across scenarios in the growth rates of exporters. The weaker increase in innovation by exporters, when the trade liberalization is perceived to be temporary, leads to a smaller increase in the share of exporters' domestic revenue (see Panel C). Hence, endogenous innovation matters less for aggregate transition dynamics when the trade liberalization is expected to be temporary.

\section{Scenario 6: Anticipated Trade Liberalization}

We just saw how firms' expectations regarding the permanence of trade liberalization affects the response of endogenous innovation. In a similar way, the response of endogenous innovation is also sensitive to firms' anticipation regarding the initial onset of trade liberalization. To highlight this, we construct a scenario where the initial trade liberalization is anticipated 2 years ahead to the actual decrease in trade costs, and focus on that 2 year period where the trade cost has not yet decreased (but is anticipated to do so). Panel A of Figure 8 shows the time path of the trade cost, which is "announced" to the firms at $t=0$. Panel B shows how exporters increase their innovation intensity upon this announcement, ahead of the anticipated drop in the trade cost. This increase in innovation is then reflected in a higher growth rate for exporters, which results in an increasing share of exporters in domestic revenues in Panel $\mathrm{C}$ (ahead of the reduction in the trade cost). ${ }^{23}$

The anticipated response of innovation in this scenario is driven by the firms' desire to smooth their innovation activities over time in response to the higher benefits to innovate: As the cost of innovation is convex, firms do not want to cluster their innovation activities right before the drop in the trade cost, and prefer to spread them out ahead of the anticipated liberalization.

\section{Scenario 7: Temporary Trade Liberalization and Sunk Export Costs}

In our last two scenarios, we examine the consequences for the dynamics of trade liberalization that relate to the export entry decision in the presence of sunk export costs. We introduce (partial) irreversibility of the export decision by assuming that some of the fixed export costs are sunk. In particular, in addition to the fixed export costs $f_{X}$, we assume that a non-exporter that becomes an exporter must hire $f_{X S}$ units of labor during the first period as an exporter. An exporter that stops exporting must incur these sunk costs to re-start exporting.

\footnotetext{
${ }^{23}$ Furthermore, the associated rise in the share of exporters in domestic revenues (in advance of the decline in trade costs) is larger than it is for the case of exogenous innovation (see solid line in Panel E of Figure 8).
} 
With sunk export costs, the choice to enter the export market is no longer a static decision as in expression (14). Instead, current export entry decisions are shaped by expected future exporting profits, subject to firms' expectations regarding their idiosyncratic productivity and the path of trade costs. This represents an additional channel that generates endogenous aggregate transition dynamics from trade liberalization. Since this channel operates independently of the endogenous innovation response, we highlight its effect using the case of exogenous innovation. We first examine how export entry decisions under sunk export costs interact with the perceived persistence of trade liberalization. Figure 9, Panel A, depicts the path of trade costs under a temporary (i.e. lasting 4 years) and a permanent trade liberalization. In both cases, the liberalization is initially unanticipated.

As a reference point, we first consider our baseline model calibrated with only fixed export costs (and exogenous innovation). In this case the perceived permanence of the reduction in trade costs has little bearing on export decisions (because entry into exporting is a static decision based on the level of current profits from exporting). This implies, as shown in Panel B, that the increase in the share of exporters in domestic revenues over the first 4 years of the trade liberalization is very similar in both the temporary and permanent cases.

Next, we designate a proportion of the fixed export cost to be sunk. In particular, we set the fixed export cost at a low level $\left(f_{X}=0.2\right)$, and choose $f_{X S}$ to match our baseline calibration targets. In this case, entry of non-exporters into exporting is stronger when the reduction in trade costs is perceived to be permanent. This can be seen in Panel C: Over the first 4 years, the rise in the share of exporters in domestic revenues (and hence also the overall response of trade volumes) is larger in the permanent case than in the temporary case. That is, trade liberalization must be perceived to be long-lasting in order to provide incentives for firms to pay the sunk export cost. ${ }^{2425}$

\footnotetext{
${ }^{24}$ This result is similar to the one in Ruhl (2008). The latter shows how sunk export costs induce a larger response of exports to permanent shocks (i.e. trade liberalization) than to temporary shocks (i.e. business cycles). See also the related work by Albuquerque and Rebelo (2000).

${ }^{25}$ Note also that the nature of fixed export costs shapes the strength of the short run response of entry into export markets. In particular, comparing Panels B and C for either the temporary or the permanent trade liberalization case, we see that the short-run increase in the share of exporters in their domestic market (and hence the overall response of trade volumes) is much larger under fixed export costs than under sunk export costs. In contrast, the long-run responses of the trade volumes are very similar under fixed or sunk export costs (projecting the responses beyond the 10 years displayed in the figures). The hysteresis band in export participation (that we describe in the next Scenario) plays an important role in generating this difference in the short run responses.
} 


\section{Scenario 8: Anticipated Trade Liberalization and Sunk Export Costs}

We now illustrate a second implication of export entry decisions in the presence of export sunk costs for the aggregate dynamics following trade liberalization. Here we focus on an anticipated trade liberalization, as described in Scenario 6. In the presence of productivity dynamics, sunk export costs generate an option value associated with the export market entry decision, and an associated hysteresis band: There is a set of firms (associated with productivity $z$ in a given range) whose export decision is determined by their prior export status. This option value is sensitive to the firms' expectations regarding future trade costs, and thus responds to announcements regarding those future costs.

As a useful starting point, consider first a version of our model with no productivity dynamics $\left(\Delta_{z}=0\right)$. In the initial equilibrium before trade liberalization is announced, the static profit gain from exporting for any non-exporting firm $z$ must be lower than the sum of the fixed export cost, $f_{X}$, and the per-period flow value of the sunk cost, $\frac{R+\delta-1}{R} f_{X S}$ :

$$
\left(\tau^{1-\rho}-1\right) \Pi_{D} \exp (z)<f_{X}+\frac{R+\delta-1}{R} f_{X S}
$$

Consider now the periods after trade liberalization is announced but ahead of the actual reduction in trade $\operatorname{costs} \tau$. Abstracting from general equilibrium changes in the domestic market demand index $\Pi_{D}$, and in the interest rate $R$, condition (20) remains unchanged. That is, before the reduction in trade costs, it is still the case that the static profit gains from exporting are lower than the annual fixed and sunk costs of export. Therefore, firms that were non-exporters before the announced trade liberalization will not find it optimal to start exporting ahead of the reduction in trade costs. Once the reduction in trade costs is materialized, condition (20) will be reversed for some firms, who will then start exporting. Without productivity dynamics (and abstracting from some general equilibrium considerations before the reduction in trade costs), sunk export costs do not give rise to anticipated changes in export decisions. A similar argument can be applied to the innovation decision. Abstracting from general equilibrium changes in $\Pi_{D}$ and $R$, there would be no incentive to innovate ahead of the reduction in trade costs (in contrast to the results under Scenario 6).

Figure 10 shows how the combination of sunk export costs and productivity dynamics does result in changes in export decisions ahead of the reduction in trade costs. The path and announcement regarding the trade costs are identical to Scenario 6 (depicted again in Panel A). We run one simulation using our previously calibrated model with only fixed export costs, and then another one 
with sunk export costs (parameterized as described for Scenario 7). Both cases include productivity dynamics $\left(\Delta_{z}>0\right)$ but exogenous innovation, and take into account the general equilibrium changes in the domestic market demand index $\Pi_{D}$, and in interest rate $R$.

Panel B shows how the option value associated with the sunk export cost induces the entry of firms into the export market - captured by the rising share of exporters in domestic revenues ahead of the decrease in the trade cost. In the pre-liberalization steady state, some firms just below the export cost cutoff do not export due to the option value associated with waiting (to export): they want to mitigate potential losses from an adverse productivity shock following export market entry. The announcement of future trade liberalization then substantially reduces this option value of waiting to export for those firms (the consequences of a future adverse shock are not as dire, as those firms would still choose to export so long as the per-unit trading costs are reduced); and those firms enter the export market ahead of the reduction in trade costs. This is reflected in the increased share of exporters in domestic revenues ahead of the trade liberalization. This increase is substantially larger in the model with sunk export costs than in the model with only fixed export costs.

Productivity dynamics are key for this result. Without productivity dynamics $\left(\Delta_{z}=0\right)$ there are no noticeable differences in the aggregate response of the economies with fixed and sunk export costs (even considering the general equilibrium effects on $\Pi_{D}$ and $R$ that we abstracted from in our analytic derivation above). ${ }^{26}$

\section{Conclusions}

In this chapter, we have reviewed the recent literature that incorporates firm dynamics in models of international trade. We have characterized key model ingredients that generate substantial aggregate transition dynamics stemming from endogenous shifts in the firm-size distribution in response to trade liberalization. We showed how two ingredients, export market selection and firm dynamics, are jointly needed to generate any endogenous transition dynamics. We then examined the aggregate effects resulting from endogenous innovation responses and the anticipation effects regarding the timing of trade liberalization (when it is expected to begin, and whether it is temporary or permanent). Our computational results show how the responses of trade volumes, innovation, and aggregate output vary greatly over time depending on the details assumed for firm dynamics, en-

\footnotetext{
${ }^{26}$ Bergin and Lin (2010) study an alternative mechanism, based on heterogeneity in sunk-export costs across firms. In this setup, some firms also enter export markets in anticipation of future trade liberalization.
} 
dogenous innovation, and the expected time path of the trade liberalization. This has important consequences for many issues in international economics that rely on predictions for the effects of globalization over time on those key aggregate outcomes such as trade volumes, innovation, and aggregate productivity (an endogenous source of comparative advantage). ${ }^{27}$ For empirical work, it is important to recognize that a measured response to globalization at a given point in time represents just one snapshot for the effects of globalization: one that may evolve considerably in the future (without any subsequent changes to economic fundamentals), and one that is sensitive to many unobservables regarding firms' expectations and anticipations.

In order to keep our analysis tractable, we have limited our modeling exercise to just one form of international market participation (exports) and one form of innovation. As we noted in our introduction, the literature has examined many other forms of international market participation. Our choice should not be construed to imply that dynamics are more important for exports than for those other forms of market participation. We picked exports as an example (one that is very well understood) to highlight the importance of dynamic considerations. Similarly, we recognize that we modeled innovation in a coarse, reduced form way. First, we have assumed that only labor is used for innovative activities, and thus have not captured how globalization may affect the cost of innovation via changes in other input costs or spillovers. Second, we have not explicitly specified the channels through which innovation/investment activities generate performance improvements - other than through a direct effect on labor productivity. Such channels could include management quality, offshoring that breaks-up the production chain, development of a firm's product range, changes in input usage due to the availability of imported intermediates, and marketing/relationship building with foreign buyers. Many of these factors apply differentially across a firm's destination markets, and could hence result in destination-specific dynamics that differ from those of our model in which productivity improvements apply world-wide. These are all fruitful areas for future work.

\section{References}

[1] Aghion, P., Bloom, N., Blundell, R., Griffith, R., \& Howitt, P. (2005). Competition and Innovation: An Inverted-U Relationship. Quarterly Journal of Economics, 120(2), 701-728.

[2] Albuquerque, R, \& Rebelo, S. (2000). On the Dynamics of Trade Reform. Journal of International Economics, Elsevier, 51(1), 21-47.

\footnotetext{
${ }^{27}$ Note that the consequences of those modeling assumptions for welfare outcomes is substantially more muted. This is discussed in much greater detail in Atkeson and Burstein (2010).
} 
[3] Alessandria, G., \& Choi, H. (2007). Establishment Heterogeneity, Exporter Dynamics, and the Effects of Trade Liberalization. Mimeo.

[4] Alessandria, G., Midrigan, V., and Kaboski, J. (2010). Inventories, Lumpy Trade and Large Devaluations. American Economic Review. 100(5): 2304-39,

[5] Arkolakis, C. (2008). Market Penetration Costs and the New Consumers Margin in International Trade. NBER Working Paper.

[6] Arkolakis, C., Costinot, A., \& Rodríguez-Clare, A. (2010). New trade models, same old gains? NBER Working Paper.

[7] Atkeson, A., \& Burstein, A. T. (2010). Innovation, Firm Dynamics, and International Trade. Journal of Political Economy, 118(2010), 433-84.

[8] Atkeson, A., \& Kehoe, P. J. (2005). Modeling and Measuring Organization Capital. Journal of Political Economy, 113(5), 1026-53.

[9] Aw, B.Y, Roberts, M., \& Xu, Y.D (Forthcoming). R\&D Investment,Exporting, and Productivity Dynamics. American Economic Review.

[10] Bergin, P. R., \& Lin, C. Y. (2008). Exchange Rate Regimes and the Extensive Margin of Trade. NBER Working Paper.

[11] Bernard, A. B., \& Jensen, J. B. (2004). Entry, expansion, and intensity in the US export boom, 1987-1992. Review of International Economics, 12(4), 662-675.

[12] Bernard, A. B., Jensen, J. B., \& Schott, P. K. (2006). Survival of the best fit: Exposure to lowwage countries and the (uneven) growth of US manufacturing plants. Journal of International Economics, 68(1), 219-237.

[13] Bernard, A. B., \& Jensen, J. B. (2004). Why Some Firms Export. Review of Economics \& Statistics, 86(2), 561-569.

[14] Bernard, A. B., \& Wagner, J. (2001). Export Entry and Exit by German Firms. Weltwirtschaftliches Archiv, 137(1), 105-123.

[15] Bloom, N., Draca, M., \& Van Reenen, J. (2008). Trade induced technical change? The impact of Chinese imports on IT and innovation. Mimeo.

[16] Buera, F. J., \& Shin, Y. (2009). Productivity Growth and Capital Flows: The Dynamics of Reforms. NBER Working Papers.

[17] Bustos, P. (2011). Trade Liberalization, Exports and Technology Upgrading: Evidence on the Impact of MERCOSUR on Argentinean Firms. American Economic Review, 101(1), 304-40.

[18] Chaney, T. (2011). The Network Structure of International Trade. Mimeo.

[19] Cosar, K. \& Guner, N. \& Tybout, J. (2010). Firm Dynamics, Job Turnover, and Wage Distributions in an Open Economy. NBER Working Paper.

[20] Cosar, K. 2011. Adjusting to Trade Liberalization: Reallocation and Labor Market Policies. Mimeo. 
[21] Costantini, J., \& Melitz, M. J. (2009). The dynamics of firm-level adjustment to trade liberalization. In The Organization of Firms in a Global Economy. Harvard University Press.

[22] Das, S., Roberts, M. J., \& Tybout, J. R. (2007). Market entry costs, producer heterogeneity, and export dynamics. Econometrica, 75(3), 837-873.

[23] Dix-Carneiro, R. (2010). Trade Liberalization and Labor Market Dynamics. Mimeo.

[24] Doraszelski, U., \& Jaumandreu, J. (2010). R\&D and productivity: Estimating production functions when productivity is endogenous. Mimeo.

[25] Eaton, J., Eslava, M., Krizan, C. J., Kugler, M., \& Tybout, J. (2008). A search and learning model of export dynamics. Mimeo.

[26] Ederington, J., \& McCalman, P. (2008). Endogenous Firm Heterogeneity and the Dynamics of Trade Liberalization. Journal of International Economics, 74(2), 422-440.

[27] Ericson, R., \& Pakes, A. (1995). Markov-perfect industry dynamics: A framework for empirical work. The Review of Economic Studies, 53-82.

[28] Fajgelbaum, P. (2010). Labor Market Frictions, Firm Growth and International Trade. Mimeo.

[29] Fattal Jaef, R. (2010). Entry, Exit and Mis-allocation Frictions. Mimeo.

[30] Foster, L., Haltiwanger, J., and Syverson, C. (2010). The Slow Growth of New Plants: Learning about Demand. Mimeo.

[31] Greenaway, D., \& Kneller, R. (2007). Industry differences in the effect of export market entry: learning by exporting? Review of World Economics, 143(3), 416-432.

[32] Griliches, Z. (1979). Issues in assessing the contribution of research and development to productivity growth. The Bell Journal of Economics, 10(1), 92-116.

[33] Hopenhayn, H. A. (1992). Entry, Exit, and Firm Dynamics in Long Run Equilibrium. Econometrica, 60(5), 1127-1150.

[34] Kambourov, G. (2009). Labor Market Regulations and the Sectoral Reallocation of Workers: The Case of Trade Reforms. Review of Economic Studies, 76(4): 1321-1358.

[35] Lileeva, A., \& Trefler, D. (2010). Improved Access to Foreign Markets Raises Plant-Level Productivity... for Some Plants. Quarterly Journal of Economics, 125(3), 1051-1099.

[36] Lopez, R. A. (2005). Trade and Growth: Reconciling the Macroeconomic and Microeconomic Evidence. Journal of Economic Surveys, 19(4), 623-648.

[37] Luttmer, E. (2007). Selection, Growth, and the Size Distribution of Firms. Quarterly Journal of Economics, 122(3): 1103-1144.

[38] Luttmer, E. (2010). Models of Growth and Firm Heterogeneity. Annual Reviews of Economics. 2: $547-576$.

[39] Navas-Ruiz, A., \& Sala, D. (2007). Technology Adoption and the Selection Effect of Trade. Mimeo. 
[40] Roberts, M. J., \& Tybout, J. R. (1997a). What makes exports boom? World Bank Publications.

[41] Roberts, M. J., \& Tybout, J. R. (1997b). The Decision to Export in Colombia: An Empirical Model of Entry with Sunk Costs. American Economic Review, 87(4), 545.

[42] Rubini, L. (2010). Innovation and the Elasticity of Trade Volumes to Tariff Reductions. Mimeo.

[43] Ruhl, K. J. (2008). Solving the Elasticity Puzzle in International Economics. Mimeo.

[44] Van Long, N., Raff, H., \& Stähler, F. (2009). Innovation and Trade with Heterogeneous Firms. Mimeo.

[45] Verhoogen, E. A. (2008). Trade, Quality Upgrading, and Wage Inequality in the Mexican Manufacturing Sector. Quarterly Journal of Economics, 123(2), 489-530.

[46] Yeaple, S. R. (2005). Firm Heterogeneity, International Trade, and Wages. Journal of International Economics, 65(1), 1-20. 
Table 1: Baseline Parametrization

\begin{tabular}{|c|c|c|}
\hline Calibrated Parameters & $\begin{array}{l}\text { Exogenous } \\
\text { (Inelastic) } \\
\text { Innovation }\end{array}$ & $\begin{array}{l}\text { Endogenous } \\
\quad \text { (Elastic) } \\
\text { Innovation }\end{array}$ \\
\hline Exogenous exit rate $\delta$ & 0.005 & 0.005 \\
\hline Innovation step size $\Delta z$ & 0.25 & 0.25 \\
\hline Level of innovation cost function $h$ & - & 0.00108 \\
\hline $\begin{array}{l}\text {.. or implied Pareto coefficient } \\
\text { (employment distribution of large firms) }\end{array}$ & -0.25 & -0.25 \\
\hline Marginal trade cost $\tau$ & 0.231 & 0.231 \\
\hline Fixed costs of international trade $f_{X}$ & 1.4 & 0.285 \\
\hline Targets & \multicolumn{2}{|c|}{ Data } \\
\hline $\begin{array}{l}\text { Employment growth rate of large firms } \\
\text { (standard deviation) }\end{array}$ & \multicolumn{2}{|c|}{0.25} \\
\hline $\begin{array}{l}\text { Employment-based exit rate } \\
\text { (firms with more than } 500 \text { employees) }\end{array}$ & \multicolumn{2}{|c|}{0.0055} \\
\hline $\begin{array}{l}\text { Pareto coefficient for employment-based } \\
\text { size distribution ( } 1,000 \text { to } 5,000 \text { employees })\end{array}$ & \multicolumn{2}{|c|}{-0.20} \\
\hline $\begin{array}{l}\text { Exports / Gross Output } \\
\text { (of intermediate goods in model) }\end{array}$ & \multicolumn{2}{|c|}{0.075} \\
\hline $\begin{array}{l}\text { Employment share of exporters } \\
\text { (production employment in model) }\end{array}$ & \multicolumn{2}{|c|}{0.400} \\
\hline
\end{tabular}

Other Parameters

All Scenarios

Interest rate $1 / \beta$

0.05

Elasticity of substitution $\rho$

5

Entry cost $f_{E}$ 1

Overhead production cost $f \quad 0.1$

Note: All time-related parameter values are annualized 

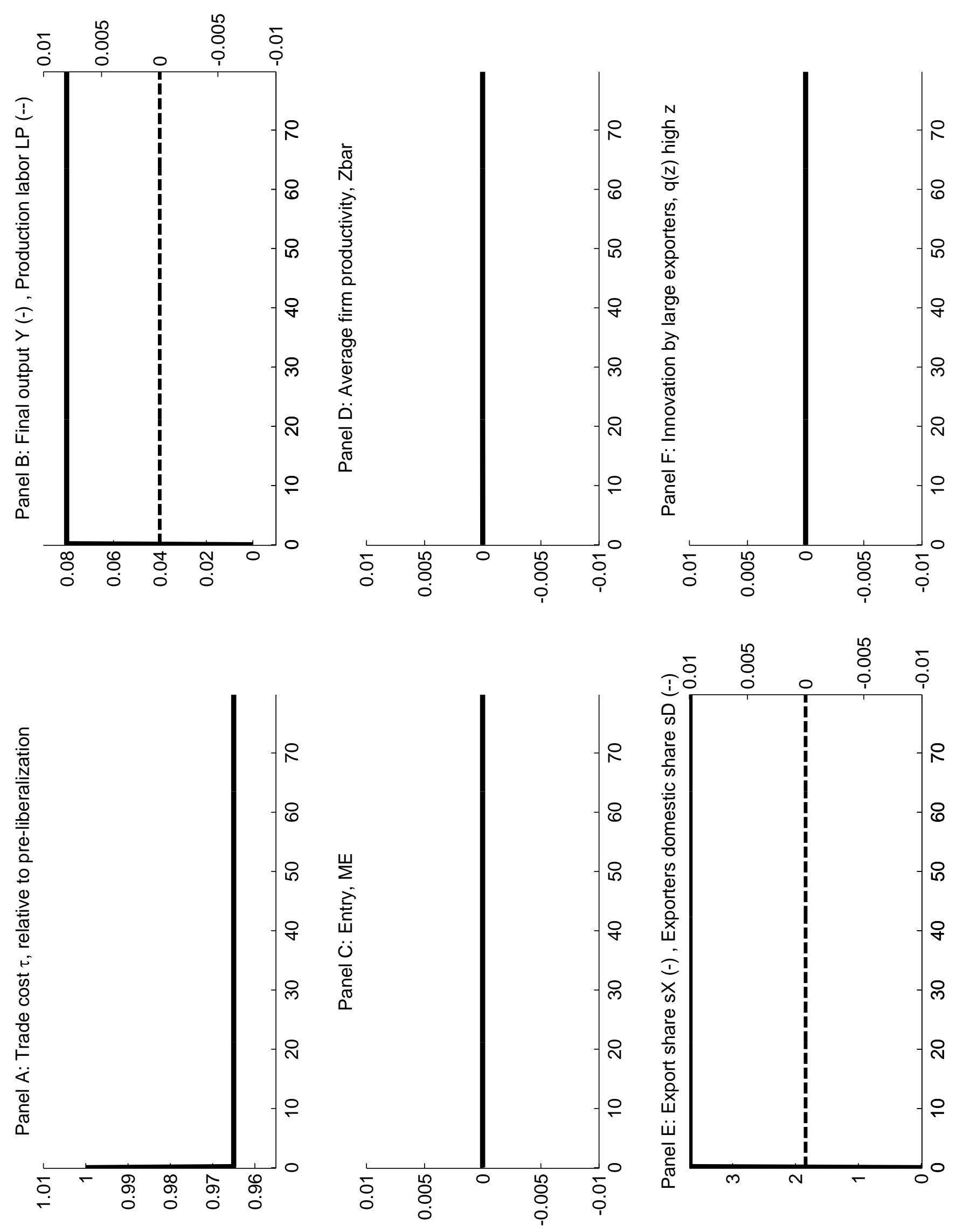

Figure 1: Scenario 1, No Export Market Selection 

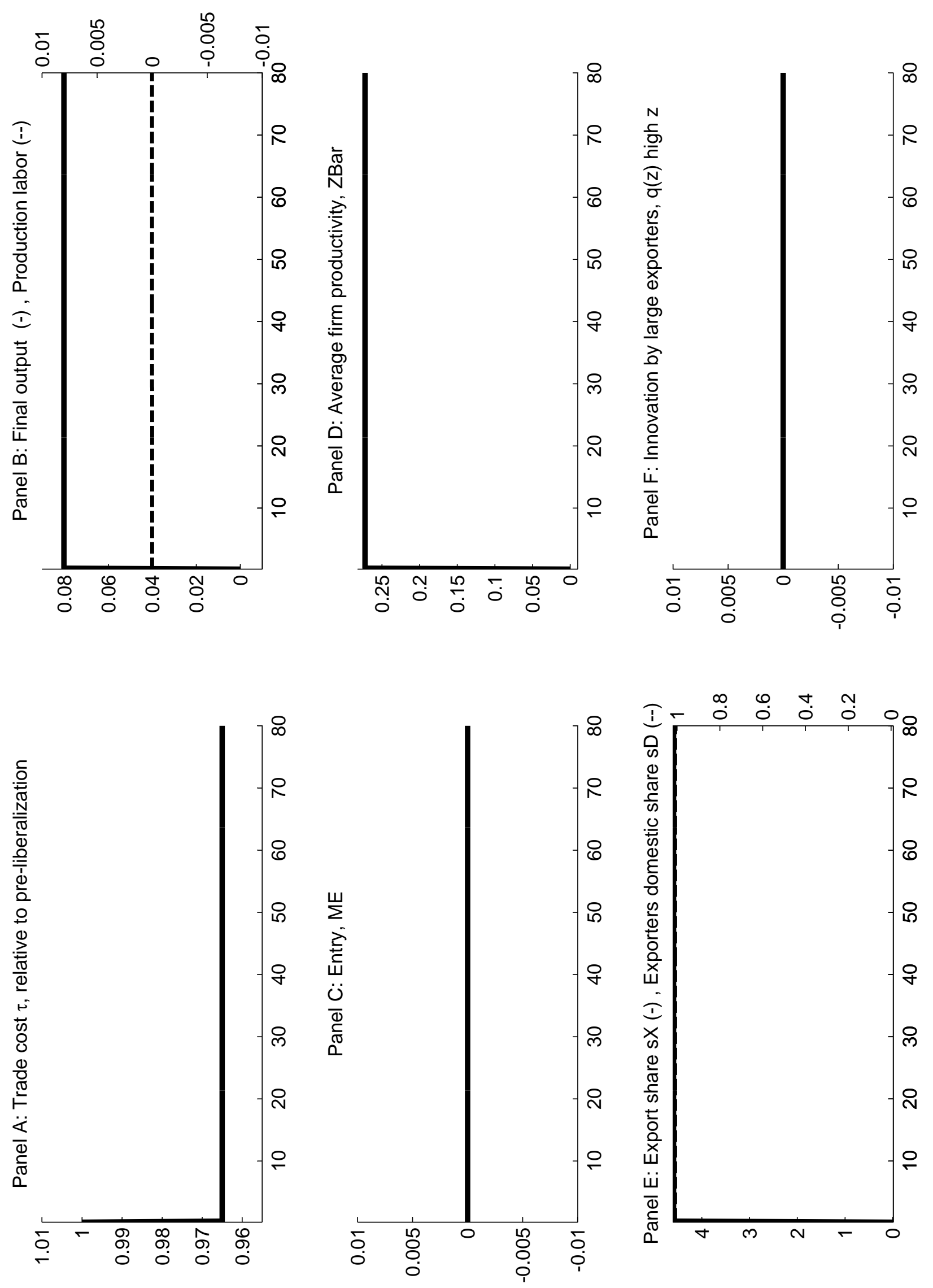

Figure 2: Scenario 2, No Firm Productivity Dynamics 

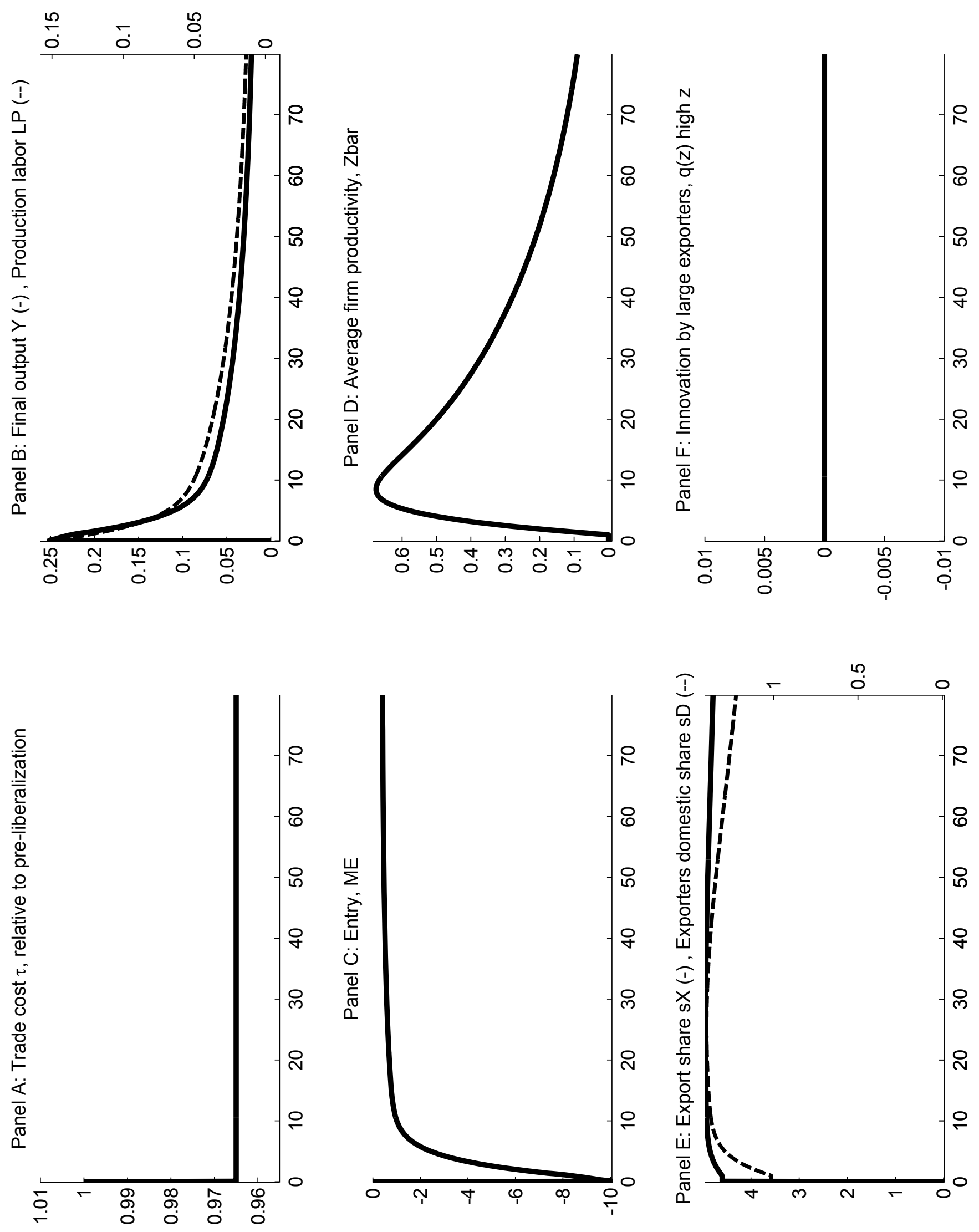

Figure 3: Scenario 3, Export Market Selection and Firm Dynamics with Exogenous Innovation 

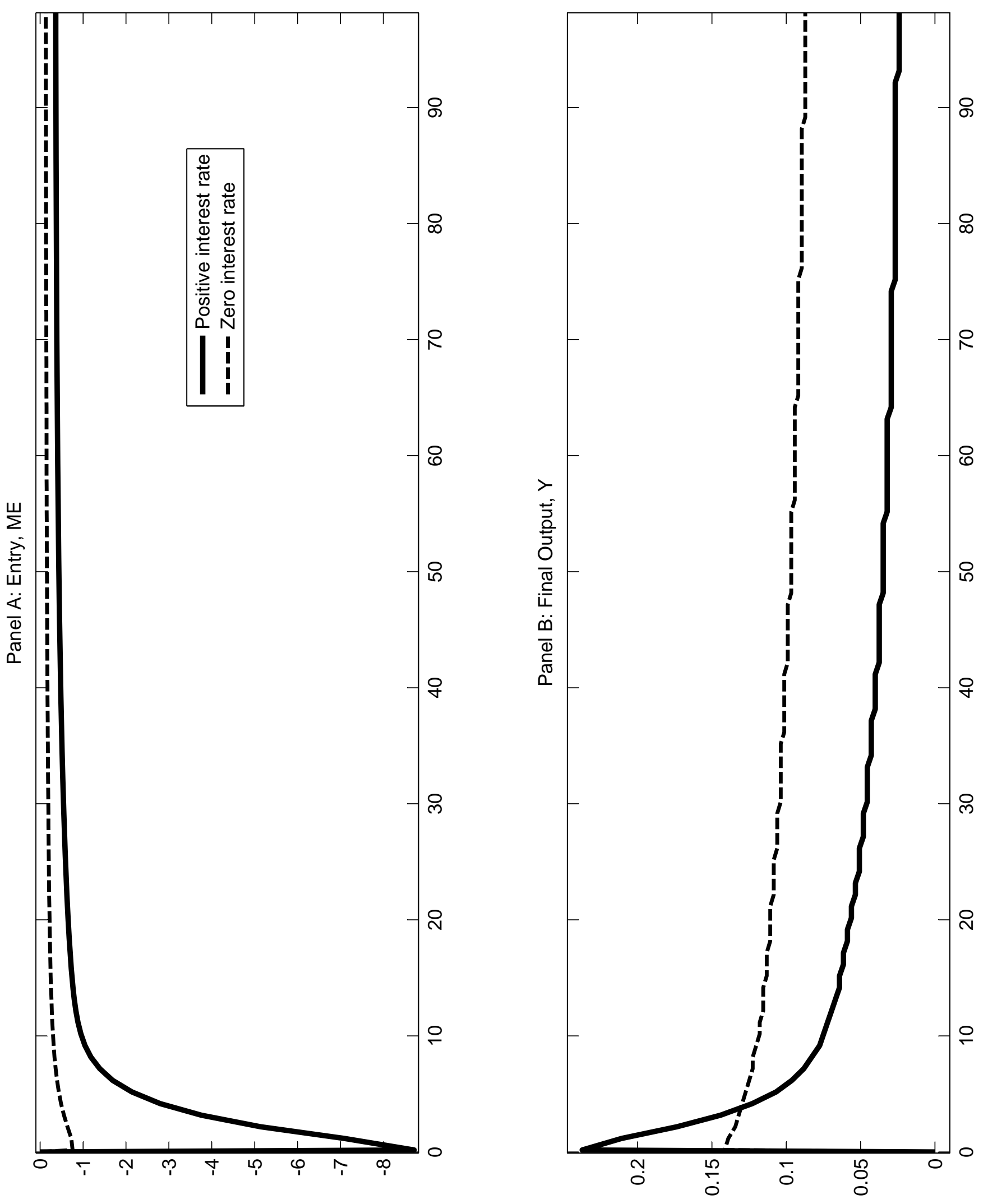

Figure 4: Scenario 3, Export Market Selection and Firm Dynamics with Exogenous Innovation, Varying the Interest Rate 

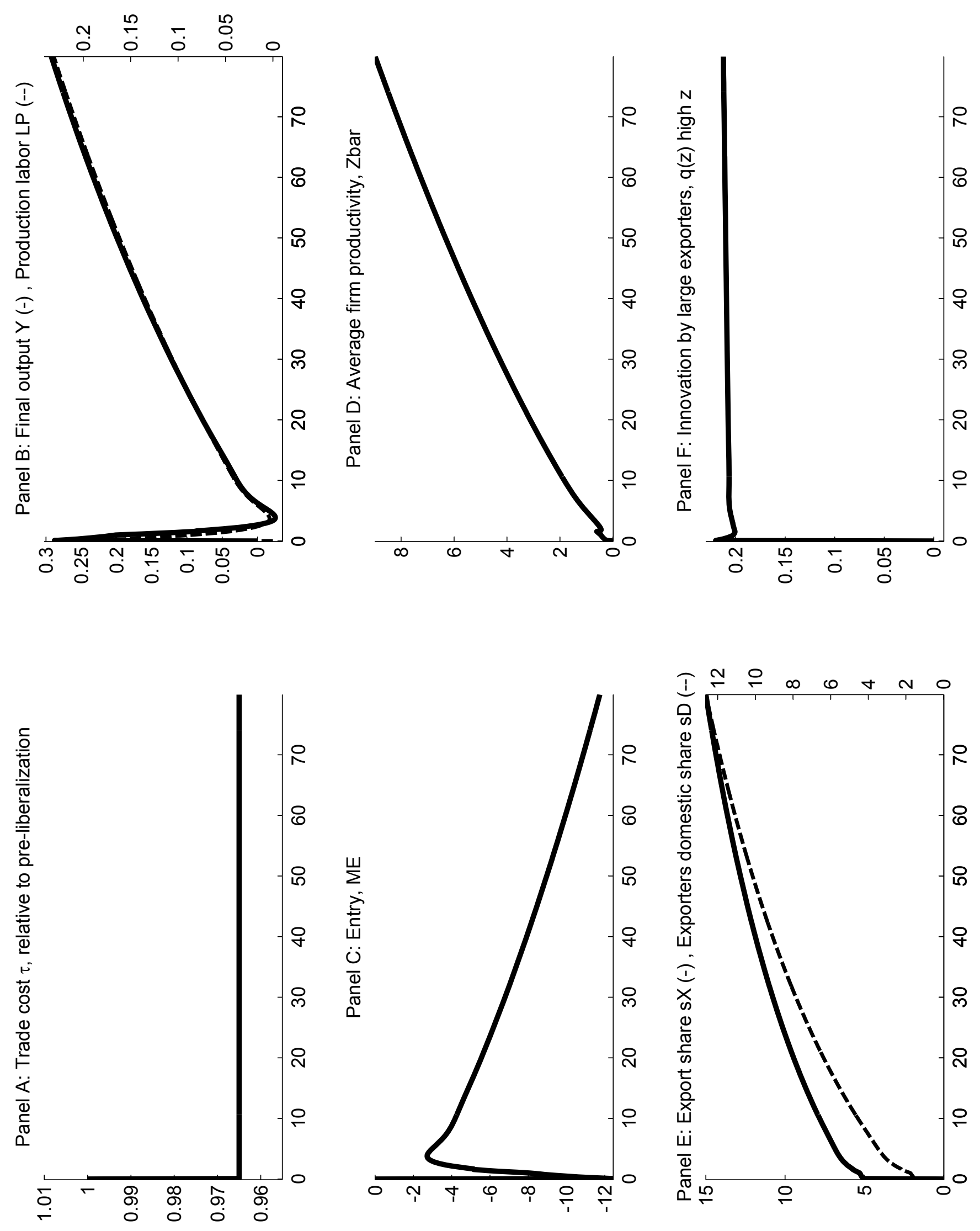

Figure 5: Scenario 4, Endogenous Export Market Selection and Endogenous Innovation 


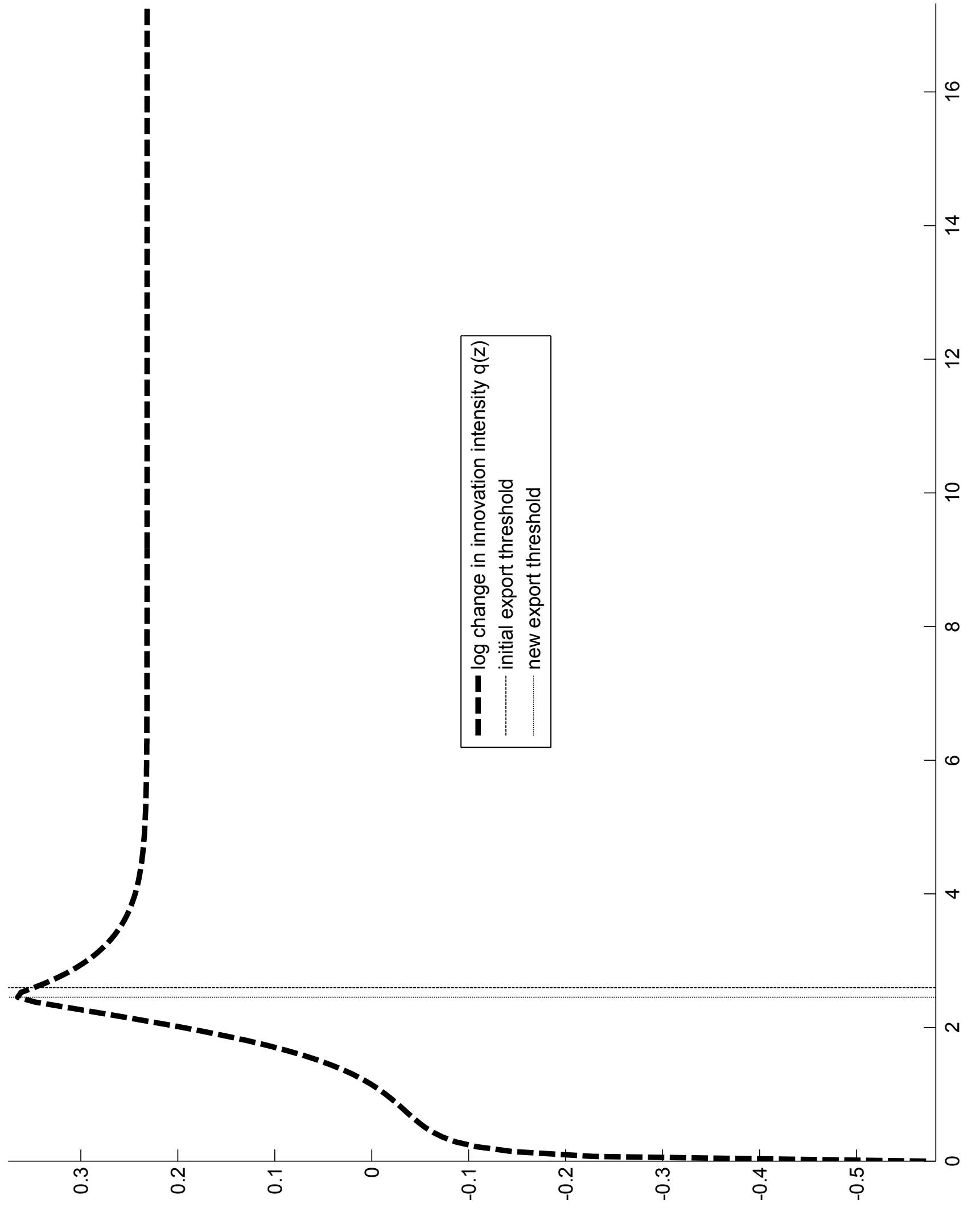

Figure 6: Scenario 4, Endogenous Export Market Selection and Endogenous Innovation, Change in Innovation Intensity 


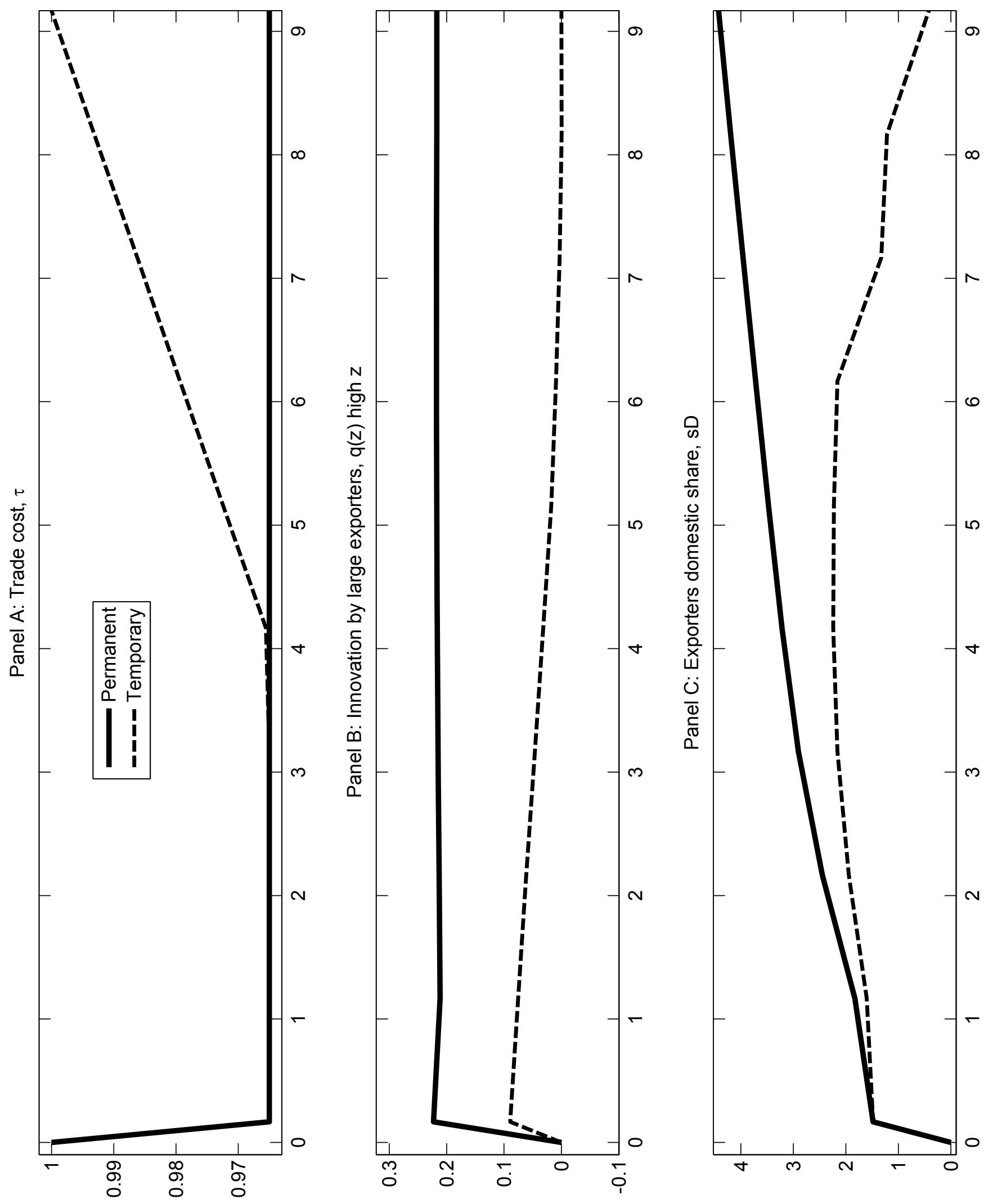

Figure 7: Scenario 5, Temporary Trade Liberalization 


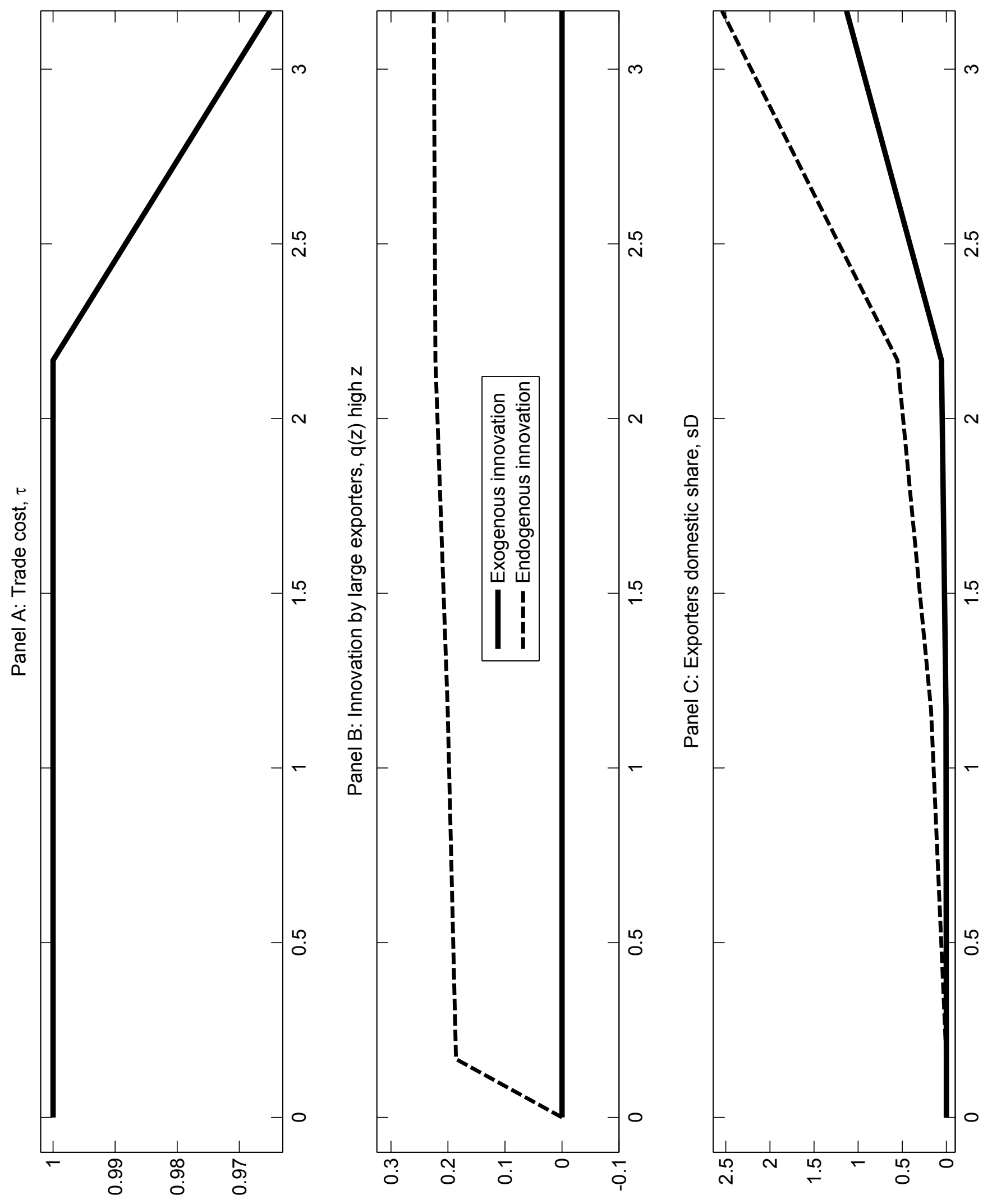

Figure 8: Scenario 6, Anticipated Trade Liberalization 

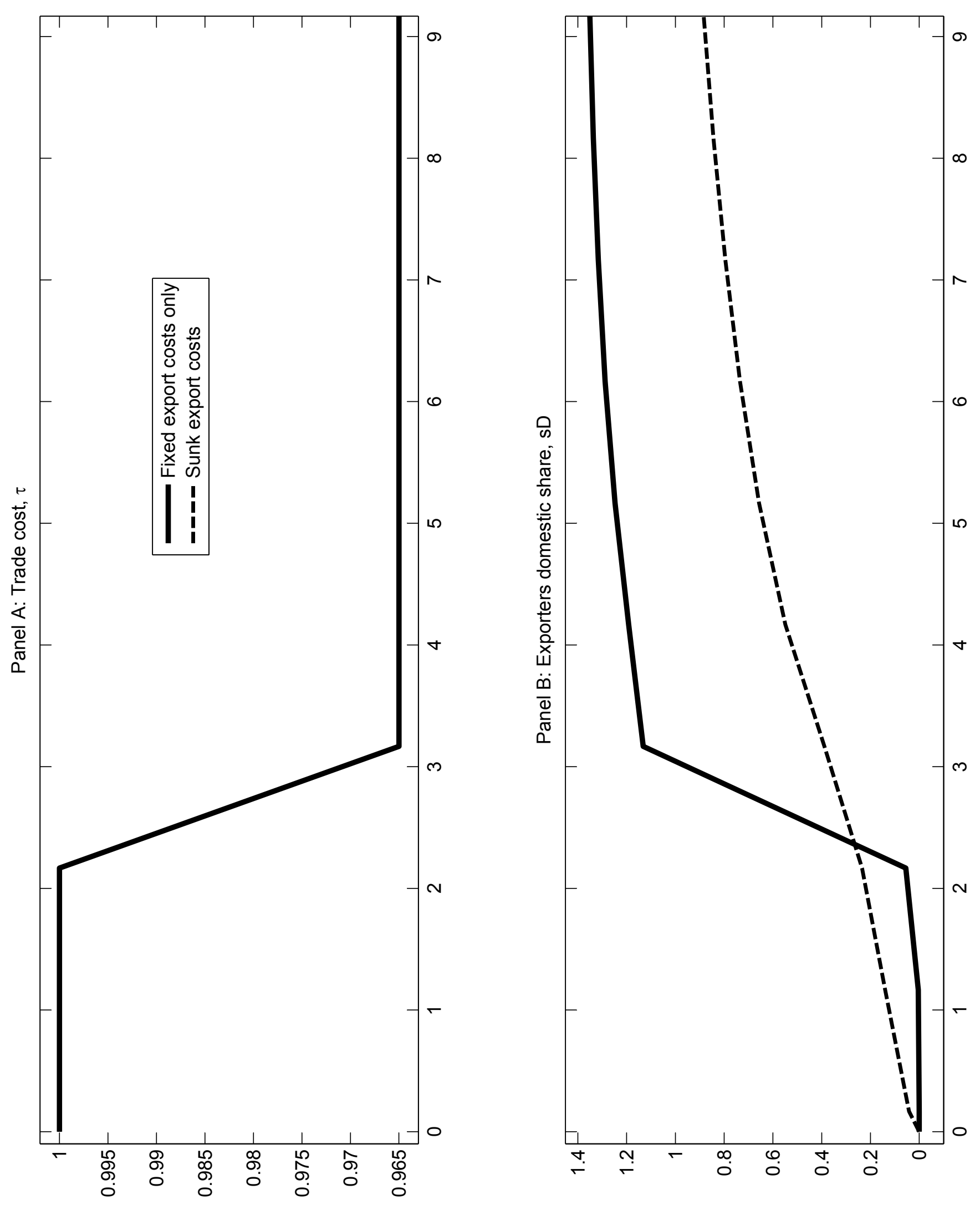

Figure 9: Scenario 7, Temporary Trade Liberalization and Sunk Export Costs 

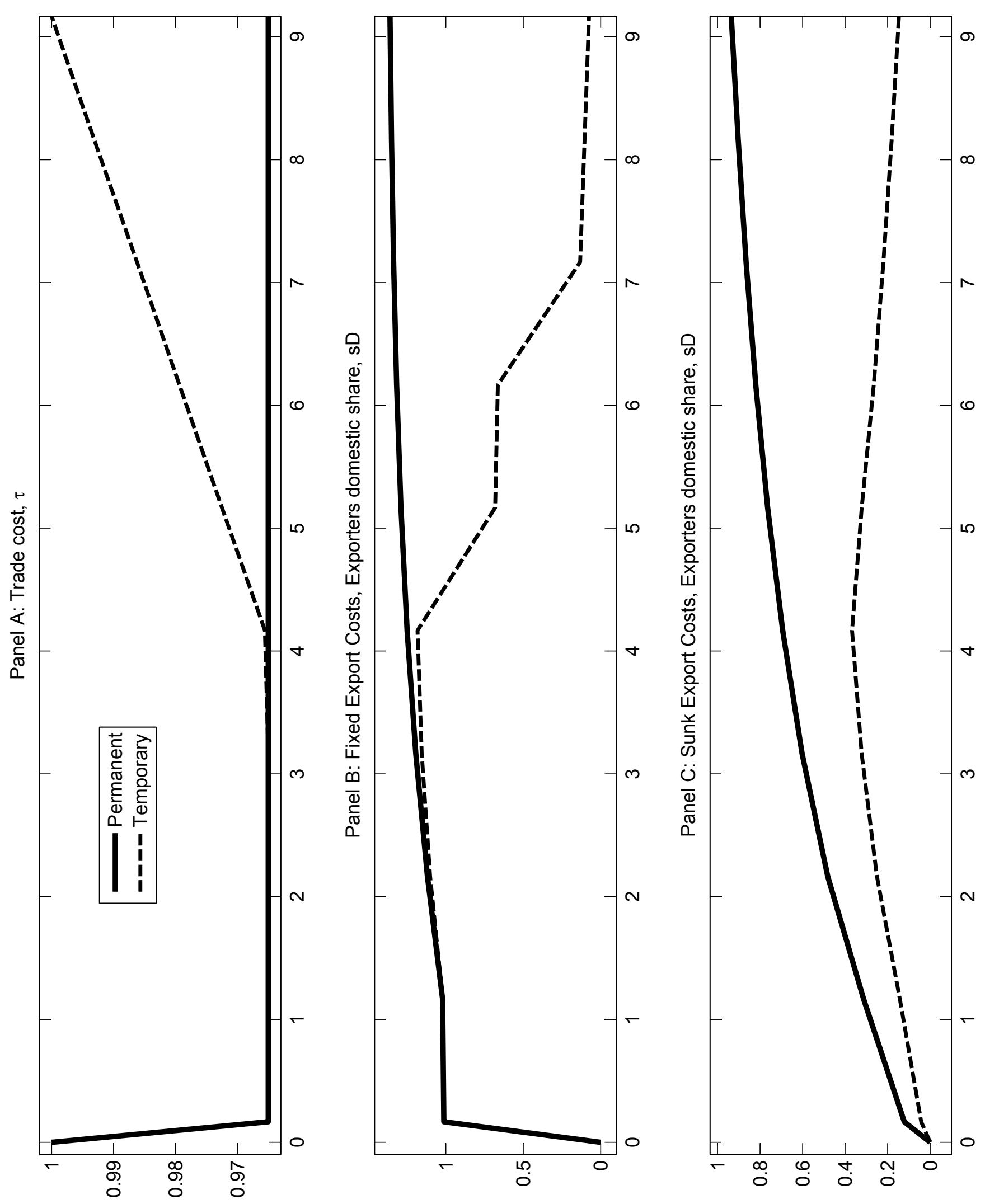

Figure 10: Scenario 8, Anticipated Trade Liberalization and Sunk Export Costs 


\section{Appendix: Analytic Results}

\section{A Solving symmetric steady-state}

For a given value of $\Pi_{D}$, export decisions are determined by the static condition that variable profits from exports must exceed fixed costs of exporting, or

$$
x(z)=1 \text { if and only if } \Pi_{D} \tau^{1-\rho} \exp (z) \geq f_{X} .
$$

The export cutoff is defined by $\Pi_{D} \tau^{1-\rho} \exp \left(\bar{z}_{X}\right)=f_{X}$. To solve for firms' steady-state exit and innovation decisions, we must solve the firms' Bellman equation, (7), removing the time subscripts from all variables and letting $R_{t}=1 / \beta$. Standard arguments give that this Bellman equation has a unique solution $V(z)$, corresponding to any given value of $\Pi_{D}$ under appropriate parameter restrictions.

We use the free-entry condition (10) to solve for the equilibrium value of $\Pi_{D}$. Using standard arguments, one can show that a unique solution for $\Pi_{D}$ exists because the value function of operating firms, $V^{o}(z)$, is strictly increasing in $\Pi_{D}$. The solution to this problem now gives us firms' exit

decisions $\bar{z}$, export decisions $x(z)$, and innovation decisions $q(z)$. These decisions, under certain parameter restrictions, imply from (13) a steady-state distribution of firms' productivities scaled by the mass of entering firms, $\tilde{M}(z)=M(z) / M_{E}$. The mass of entering firms is the solution to

$$
M_{E}\left[\frac{L_{P}}{M_{E}}+f_{E}+\int\left[\exp (z) c(q(z))+f+x(z) f_{X}\right] \tilde{M}(z) \mathrm{d} z\right]=1
$$

where $L_{P} / M_{E}=\int l(z) \tilde{M}(z) \mathrm{d} z$ is determined using (16). We can then solve aggregate output and productivity using (18) and (19), and the price level as $P=\frac{\rho}{\rho-1} \frac{1}{Z}$.

\section{B No export market selection}

We state our main result in the following proposition, which is straightforward to extend to asymmetric countries (see Atkeson and Burstein 2010).

Proposition 1: Consider a world economy with no fixed costs of trade $\left(f_{X}=0\right)$. In this economy, a permanent change in marginal trade costs from $\tau_{0}$ to $\tau$ has no impact on the equilibrium exit threshold, $\bar{z}$, innovation decisions of firms, $q(z)$, the mass of entering firms, $M_{E}$, and the ratio of exporters' revenues in the domestic market to total domestic revenues, $s_{D}$. Moreover, the economy 
transits immediately to a new steady-state in which changes in the export share, $s_{X}$, aggregate productivity, $Z$ and output, $Y$, are:

$$
\begin{gathered}
\frac{s_{X}}{s_{0 X}}=\frac{\tau^{1-\rho} /\left(1+\tau^{1-\rho}\right)}{\tau_{0}^{1-\rho} /\left(1+\tau_{0}^{1-\rho}\right)} \\
\frac{Z}{Z_{0}}=\frac{1+\tau^{1-\rho}}{1+\tau_{0}^{1-\rho}} \\
\frac{Y}{Y_{0}}=\left(\frac{1+\tau^{1-\rho}}{1+\tau_{0}^{1-\rho}}\right)^{\frac{1}{\rho-1}}
\end{gathered}
$$

Proof: We first solve for the equilibrium in a symmetric steady-state. With $f_{X}=0$ for all firms, (A.1) implies that all firms export and the variable profits of a firm with productivity $z$ are $\Pi_{D}\left(1+\tau^{1-\rho}\right) \exp (z)$. Hence, under the assumption that all firms export, the Bellman equation in the steady state, $(7)$, can be written with $\tilde{\Pi} \exp (z)$ replacing $\Pi_{t}(z)$, where $\tilde{\Pi}=\Pi_{D}\left(1+\tau^{1-\rho}\right)$. Our arguments in the previous section imply that a unique level of $\tilde{\Pi}$ exists which satisfies the free-entry condition (10), independent of the parameter $\tau$. The corresponding exit thresholds, $\bar{z}$, innovation decisions, $q(z)$, that solve the Bellman equation at this level of $\tilde{\Pi}$ are the equilibrium exit and innovation decisions. Hence, these are also independent of $\tau$. From (16), variable employment $l(z)$ for each firm is independent of $\tau$, and so is $s_{D}$ and, from (A.2), the mass of entrants. The change in the other aggregate variables immediate follow from (17), (18), and (19). Given that firms' productivity distribution $M(z)$ is unchanged across steady-state, the adjustment to the new steady-state is immediate.

\section{No productivity dynamics}

Proposition 2: Consider a world economy with positive fixed costs of trade $\left(f_{X}>0\right)$, no productivity dynamics $\left(\Delta_{z}=0\right)$, and the distribution of entering firms $G$ is such that the distribution of $\exp (z)$ is Pareto,

$$
\operatorname{cdf} \text { of } G(z)=1-\left(\frac{\exp \left(z_{0}\right)}{\exp (z)}\right)^{\sigma}, \text { for } z>z_{0}
$$

where $\sigma>1$. Suppose that both the exit and export cutoffs are interior, $\bar{z}_{D}>z_{0}, \bar{z}_{X}>z_{0}$. In this economy, a permanent reduction in marginal trade costs, $\tau$, leads to an increase in the steady-state exit cutoff, $\bar{z}$, a decline in the export cutoff, $\bar{z}_{X}$, and has no impact on the steady-state mass of entering firms, $M_{E}$. The economy transits immediately to a new steady-state. 
Proof: We first solve for the steady-state. With the Pareto distribution of entering firms and no productivity dynamics, the free-entry condition (10) can be written as

$$
\begin{aligned}
\frac{(1-\beta(1-\delta))}{\beta} f_{E}= & \frac{\sigma \exp \left(z_{0}\right)^{\sigma}}{(\sigma-1)} \Pi_{D}\left[\exp (\bar{z})^{1-\sigma}+\exp \left(\bar{z}_{X}\right)^{1-\sigma} \tau^{1-\rho}\right] \\
& -\left(\exp \left(z_{0}\right)\right)^{\sigma}\left[\exp (\bar{z})^{-\sigma} f+\exp \left(\bar{z}_{X}\right)^{-\sigma} f_{X}\right]
\end{aligned}
$$

or using the cutoff definitions in the model without productivity dynamics, $\exp (\bar{z})=f / \Pi_{D}$ and $\exp \left(\bar{z}_{X}\right)=\tau^{\rho-1} f_{X} / \Pi_{D}$,

$$
\frac{(1-\beta(1-\delta))}{\beta} f_{E}=\frac{\exp \left(z_{0}\right)^{\sigma}}{\sigma-1}\left(\Pi_{D}\right)^{\sigma}\left(f^{1-\sigma}+f_{X}^{1-\sigma} \tau^{(1-\rho) \sigma}\right)
$$

Note from this equation that a reduction in international trade costs $\tau$ results in a decline in profitability $\Pi_{D}$ and a rise in $\Pi_{D} \tau^{(1-\rho)}$. Hence, $\bar{z}_{D}$ rises and $\bar{z}_{X}$ falls.

The labor market clearing condition (A.2) can be written, using (16) and the definition of the cutoffs, as

$$
1=M_{E}\left[f_{E}+\frac{\exp \left(z_{0}\right)^{\sigma}}{\delta}\left(\Pi_{D}\right)^{\sigma}\left(\frac{\sigma(\rho-1)}{\sigma-1}+1\right)\left(f^{1-\sigma}+f_{X}^{1-\sigma} \tau^{(1-\rho) \sigma}\right)\right]
$$

Combining (C.1) and (C.2), we obtain the result that in steady-state $M_{E}$ is independent of $\tau$. In response to a permanent reduction in $\tau$, with the mass of entering firms unchanged and the exit cutoff $\bar{z}_{D}$ increasing, the transition to a new steady-state is immediate. Note that in response to an increase in $\tau$, even though the mass of entrants is unchanged, the exit cutoff falls, so the transition to the new steady-state is not immediate unless $\delta=1$.

\section{Not all firms export, with time variation in fixed export costs}

Consider the modified version of our economy described in Section 5.

Proposition 3: In this economy, a permanent reduction in marginal trade costs, $\tau$, leads to a decline (increase) in the steady-state mass of entering firms, $M_{E}$, if and only if $\tilde{s}_{X}$ is strictly lower (higher) than $s_{X}$, and the steady-state mass of entering firms remains unchanged if and only if $\tilde{s}_{X}=s_{X}$. 
Proof: The free-entry condition in this economy is

$$
\begin{aligned}
f_{E} & =\Pi_{D} \beta \sum_{t=0}^{T-1} \beta^{t}(1-\delta)^{t}+\Pi_{D}\left(1+\tau^{1-\rho}\right) \beta^{T+1}(1-\delta)^{T} \sum_{t=0}^{\infty} \beta^{t}(1-\delta)^{t} \\
& =\beta \frac{1-\beta^{T}(1-\delta)^{T}}{1-\beta(1-\delta)} \Pi_{D}+\frac{\beta^{T+1}(1-\delta)^{T}}{1-\beta(1-\delta)} \Pi_{D}\left(1+\tau^{1-\rho}\right)
\end{aligned}
$$

The share of discounted time-series revenues of exports in total discounted time-series revenues of entering firms is:

$$
\tilde{s}_{X}=\frac{\frac{\beta^{T+1}(1-\delta)^{T}}{1-\beta(1-\delta)} \Pi_{D} \tau^{1-\rho}}{\beta \frac{1-\beta^{T}(1-\delta)^{T}}{1-\beta(1-\delta)} \Pi_{D}+\frac{\beta^{T+1}(1-\delta)^{T}}{1-\beta(1-\delta)} \Pi_{D}\left(1+\tau^{1-\rho}\right)}=\frac{\beta^{T}(1-\delta)^{T} \tau^{1-\rho}}{1+\beta^{T}(1-\delta)^{T} \tau^{1-\rho}} .
$$

Given a mass of entrants $M_{E}$, the mass of non-exporters, $M_{D}$, and exporters, $M_{X}$, is

$$
M_{D}=M_{E} \frac{1-(1-\delta)^{T}}{\delta} \text { and } M_{X}=M_{E} \frac{(1-\delta)^{T}}{\delta}
$$

The share of revenues accounted for by exports is:

$$
s_{X}=\frac{M_{X} \tau^{1-\rho}}{M_{D}+M_{X}\left(1+\tau^{1-\rho}\right)}=\frac{(1-\delta)^{T} \tau^{1-\rho}}{1+(1-\delta)^{T} \tau^{1-\rho}}
$$

Note that if $\beta=1$, then $s_{X}=\tilde{s}_{X}$. Differentiating the free-entry condition,

$$
\begin{gathered}
0=\Delta \log \Pi_{D}+\frac{\beta^{T}(1-\delta)^{T}\left(1+\tau^{1-\rho}\right)}{1+\beta^{T}(1-\delta)^{T} \tau^{1-\rho}} \Delta \log \left(1+\tau^{1-\rho}\right), \text { or } \\
\Delta \log \Pi_{D}=-\frac{1+\tau^{1-\rho}}{\tau^{1-\rho}} \tilde{s}_{X} \Delta \log \left(1+\tau^{1-\rho}\right)
\end{gathered}
$$

Aggregate output and the price level are given by

$$
\begin{gathered}
Y=\left[M_{D}+M_{X}\left(1+\tau^{1-\rho}\right)\right]^{1 /(\rho-1)} L_{p} \\
\frac{1}{P}=\frac{\rho-1}{\rho}\left[M_{D}+M_{X}\left(1+\tau^{1-\rho}\right)\right]^{1 /(\rho-1)}
\end{gathered}
$$

So,

$$
\Pi_{D}=\frac{P^{\rho} Y}{\rho^{\rho}(\rho-1)^{1-\rho}}=\frac{1}{\rho^{\rho}(\rho-1)^{1-\rho}} \frac{L_{P}}{M_{E}\left(\frac{M_{X}}{M_{E}}+\frac{M_{D}}{M_{E}}\left(1+\tau^{1-\rho}\right)\right)}
$$


and log-differentiating and using the expression for $s_{X}$,

$$
\Delta \log \Pi_{D}=\Delta \log L_{P}-\Delta \log M_{E}-\frac{1+\tau^{1-\rho}}{\tau^{1-\rho}} s_{X} \Delta \log \left(1+\tau^{1-\rho}\right)
$$

or substituting,

$$
\left(s_{X}-\tilde{s}_{X}\right) \frac{1+\tau^{1-\rho}}{\tau^{1-\rho}} \Delta \log \left(1+\tau^{1-\rho}\right)=\Delta \log L_{P}-\Delta \log M_{E}
$$

We have $L_{P}=1-f_{E} M_{E}$ or

$$
\Delta \log L_{P}-\Delta \log M_{E}=-\left(\frac{f_{E} M_{E}}{L_{P}}+1\right) \Delta \log M_{E}
$$

Combining,

$$
\left(\frac{f_{E} M_{E}}{L_{P}}+1\right) \Delta \log M_{E}=\left(\tilde{s}_{X}-s_{X}\right) \frac{1+\tau^{1-\rho}}{\tau^{1-\rho}} \Delta \log \left(1+\tau^{1-\rho}\right)
$$

When trade costs fall, $\Delta \log \left(1+\tau^{1-\rho}\right)>0$, and we obtain the result stated in the proposition.

\section{E Endogenous innovation}

Here we provide some analytics to understand the response of innovation decisions $q(z)$ to changes in trade costs. To simplify our analysis, we set fixed overhead costs to zero, $f=0$, so that there is no endogenous exit, and we focus on steady-states.

We first use the Bellman equation (7) and free-entry condition (10) to determine the impact of changes in trade costs on firm profitability $\Pi_{D}$ in equilibrium. Consider the impact of a decline in the marginal cost of trade, $\tau$, on $\Pi_{D}$. Since this raises $\tau^{1-\rho}, \Pi_{D}$ has to fall in equilibrium to restore the free entry condition. Note as well that $\Pi_{D} \tau^{1-\rho}$ must rise if the free entry condition is to be satisfied. Hence, for firms that do not switch export status, the profits of exporters - proportional to $\Pi_{D}\left(1+\tau^{1-\rho}\right)$, must rise relative to the profits of non exporters. The export threshold falls so that some firms that previously did not export now start to export.

Note that the magnitude of the decline in $\Pi_{D}$ in response to a decline in international trade costs is determined in large part by the distribution $G$ of productivities of newly entering firms. If newly created firms tend to be small non-exporters, then free entry requires that the discounted expected value of profits of these firms remain roughly constant. In this case, $\Pi_{D}$ remains roughly constant and the profits of for large exporting firms, $\Pi_{D}\left(1+\tau^{1-\rho}\right)$ rises by roughly the change in 
$\left(1+\tau^{1-\rho}\right)$. In contrast, if newly created firms tend to be large exporting firms, then free entry requires that $\Pi_{D}\left(1+\tau^{1-\rho}\right)$ remains roughly constant, and $\Pi_{D}$ falls.

We now examine the impact of these equilibrium changes in firm profitability on the level of innovation. To do so, we solve for the innovation decisions $q(z)$ in $(7)$ as a function of variable profits $\Pi_{D}$ and the other parameters of the model. The Bellman equation (7) is a standard problem of valuing the profits of the firm together with an option: the option to start exporting (recall that in this section we are abstracting from the option to exit by assuming $f=0$, so $V(z)=V^{o}(z)$ ). The following Proposition characterizes the shape of the value function $V(z)$ and the innovation decision $q(z)$ in steady-state.

Proposition 4: Suppose that the fixed overhead costs is set to zero, $f=0$. Then, the value function $V(z)$ that solves $(7)$ in steady-state has the form $V(z)=A(z) \exp (z)$ with $\lim _{z \rightarrow \infty} A(z)=$ $A_{X}$ and $\lim _{z \rightarrow-\infty} A(z)=A_{D}$, and the optimal $q(z)$ has $\lim _{z \rightarrow \infty} q(z)=\bar{q}_{X}$ and $\lim _{z \rightarrow-\infty} q(z)=\bar{q}_{D}$ where $A_{D}$ and $\bar{q}_{D}$ solve

$$
\begin{gathered}
A_{D}=\frac{\Pi_{D}-c\left(\bar{q}_{D}\right)}{1-(1-\delta) \beta\left[\bar{q}_{D} \exp \left(\Delta_{z}\right)+\left(1-\bar{q}_{D}\right) \exp \left(-\Delta_{z}\right)\right]}, \\
c^{\prime}\left(\bar{q}_{D}\right)=(1-\delta) \beta A_{D}\left[\exp \left(\Delta_{z}\right)-\exp \left(-\Delta_{z}\right)\right]
\end{gathered}
$$

and $A_{X}$ and $\bar{q}_{X}$ solve these two equations with the term $\Pi_{D}$ in (E.1) replaced with $\Pi_{D}\left(1+\tau^{1-\rho}\right)$. These solutions have $A_{X}>A_{D}$ and $\bar{q}_{X}>\bar{q}_{D}$. Moreover, $A_{D}, A_{X}$ and $\bar{q}_{D}$ and $\bar{q}_{X}$ are increasing in $\Pi_{D}$, while $A_{X}$ and $q_{X}$ are decreasing in $\tau$.

Proof: The first part of the Proposition follows by construction. The term $A_{D} \exp (z)$ with $A_{D}$ given as above represents the expected discounted present value of variable profits of a firm that sets its innovation decision $q(z)$ to the constant $\bar{q}_{D}$ and which never exports. Likewise, the term $A_{X} \exp (z)$ with $A_{X}$ given as above represents the expected discounted present value of variable profits of a firm that sets its process innovation decision $q(z)$ to the constant $\bar{q}_{X}$, which always exports, and which is so large that the fixed cost of exporting $f_{X}$ is a negligible portion of its variable profits.

For the second part of the Proposition, we show that $A_{D}$ is increasing in $\Pi_{D}$. Differentiating (E.1):

$$
\frac{\partial A_{D}}{\partial\left(\Pi_{D}\right)}=\frac{1}{1-(1-\delta) \beta\left[\bar{q}_{D} \exp \left(\Delta_{z}\right)+\left(1-\bar{q}_{D}\right) \exp \left(-\Delta_{z}\right)\right]}+\frac{\partial A_{D}}{\partial \bar{q}_{D}} \frac{\partial \bar{q}_{D}}{\partial \Pi_{D}}>0
$$


where we used the fact that innovation choice is optimal, $\partial A_{D} / \partial \bar{q}_{D}=0$, and

$$
(1-\delta) \beta\left[\bar{q}_{D} \exp \left(\Delta_{z}\right)+\left(1-\bar{q}_{D}\right) \exp \left(-\Delta_{z}\right)\right]<1
$$

to guarantee that the discounted value of profits is finite. This same logic can be used to show that $A_{X}>A_{D}, A_{X}$ is increasing in $\Pi_{D}$, and $A_{X}$ is decreasing in $\tau$.

For the third part of the Proposition, we show that $\bar{q}_{D}$ is increasing in $A_{D}$. Differentiating (E.2):

$$
\frac{\partial \bar{q}_{D}}{\partial A_{D}} \frac{\partial A_{D}}{\partial \Pi_{D}}=\frac{(1-\delta)}{c^{\prime \prime}\left(\bar{q}_{D}\right)} \beta\left[\exp \left(\Delta_{z}\right)-\exp \left(-\Delta_{z}\right)\right] \frac{\partial A_{D}}{\partial \Pi_{D}}>0
$$

where we used $\frac{\partial A_{D}}{\partial \Pi_{D}}>0$, and the assumption that $c^{\prime \prime}\left(\bar{q}_{D}\right)>0$. The same logic is used to show that $\bar{q}_{X}$ is increasing in $\Pi_{D}$ and decreasing in $\tau$.

This Proposition implies that for very small firms, the innovation decision $q(z)$ is constant at $\bar{q}_{D}$ across firms. These firms do not export and all grow at the constant rate $\left[\bar{q}_{D} \exp \left(\Delta_{z}\right)+\left(1-\bar{q}_{D}\right) \exp \left(-\Delta_{z}\right)\right]$ in expectation. Likewise, for very large firms, the innovation decision $q(z)$ is constant at $\bar{q}_{X}$ across firms. These firms do export and all grow at the constant rate $\left[\bar{q}_{X} \exp \left(\Delta_{z}\right)+\left(1-\bar{q}_{X}\right) \exp \left(-\Delta_{z}\right)\right]$ in expectation. The intuition for how $A_{i}$ and $\bar{q}_{i}$ change with changes in profitability is then straightforward. If $\Pi_{D} \exp (z)$ or $\Pi_{D}\left(1+\tau^{1-\rho}\right) \exp (z)$ rise, this raises the spread between the value of a firm that successfully innovates to $z+\Delta_{z}$ relative to the same firm that fails to innovate and falls to $z-\Delta_{z}$. From equation (9), this increased spread in profits raises the incentives to engage in innovation.

Note that the responsiveness of very large and very small firms' innovation decisions $\bar{q}_{X}$ and $\bar{q}_{D}$ to changes in profitability and marginal trade costs is determined by the curvature of the innovation cost function as indexed by $c^{\prime \prime}(q) / c^{\prime}(q)$. In particular, because the innovation choice is optimal, $\partial A_{i} / \partial \bar{q}_{i}=0$, and hence the change in steady state innovation with a change in profits is given by

$$
d \bar{q}_{D}=\frac{c^{\prime}\left(\bar{q}_{D}\right)}{c^{\prime \prime}\left(\bar{q}_{D}\right)} \frac{d\left(\Pi_{D}\right)}{\Pi_{D}-c\left(\bar{q}_{D}\right)} \quad \text { and } \quad d \bar{q}_{X}=\frac{c^{\prime}\left(\bar{q}_{X}\right)}{c^{\prime \prime}\left(\bar{q}_{X}\right)} \frac{d\left(\Pi_{D}\left(1+\tau^{1-\rho}\right)\right)}{\Pi_{D}\left(1+\tau^{1-\rho}\right)-c\left(\bar{q}_{X}\right)} .
$$

If $c^{\prime \prime}(\cdot) / c^{\prime}(\cdot)$ is very large, then innovation decisions and firm growth rates are not very responsive to changes in firm profitability, while if this curvature is small, then innovation decisions and firm growth rates are very responsive to changes in profitability. By a similar argument, this curvature of the innovation cost function $c^{\prime \prime}(\cdot) / c^{\prime}(\cdot)$ also controls the difference in the innovation decisions and implied growth rates of very large firms $\left(\bar{q}_{X}\right)$ and very small firms $\left(\bar{q}_{D}\right)$ in a steady-state. 
With this Proposition, we have the following results regarding the impact of permanent changes in trade costs on the innovation decisions of very large firms (exporters) and very small firms (nonexporters). A reduction in the marginal costs of trade $\tau$ leads to a reduction in the innovation of very small firms and an increase in the innovation of very large firms relative to very small firms. This result follows directly from the fact that a reduction in the marginal costs of trade reduces $\Pi_{D}$ and increases $\Pi_{D}\left(1+\tau^{1-\rho}\right)$ relative to $\Pi_{D}$. The extent of reallocation of innovation from non-exporters to exporters depends in part on the size distribution of newly created firms. If newly created firms are small, then $\Pi_{D}\left(1+\tau^{1-\rho}\right)$ increases and innovation in very large firms rises in absolute terms while $\Pi_{D}$ remains roughly constant leaving innovation in small firms roughly unchanged. Conversely, if newly created firms are large exporting firms, then profits $\Pi_{D}\left(1+\tau^{1-\rho}\right)$ and innovation in these firms remains roughly unchanged, while for small firms profits and innovation falls.

Note that a reduction in the fixed costs of trade $f_{X}$, by lowering the equilibrium level of profitability $\Pi_{D}$, leads to a reduction in innovation in both very large and very small firms (note that these firms do not switch export status). Similar arguments give that a decline in the entry cost $f_{E}$ results in a decline in innovation for both very large and very small firms. 